\title{
Richard Waller and the Fusion of Visual and Scientific Practice in the early Royal Society
}

\author{
Katherine M. Reinhart ${ }^{1}$ \\ University of Cambridge
}

\begin{abstract}
:
Richard Waller, Fellow and Secretary of the Royal Society, is probably best remembered for editing Robert Hooke's posthumously published works. Yet, Waller also created numerous drawings, paintings, and engravings for his own work and the Society's publications. From precisely observed grasses to allegorical frontispieces, Waller's images not only contained a diverse range of content, they are some of the most beautiful, colorful, and striking from the Society's early years. This article argues that Waller played a distinctly important role in shaping the visual program of the Royal Society by virtue of his multiple functions as reliable administrator and translator, competent natural philosopher, and skilled image-maker. It analyzes Waller's visual works in the context of his graphic training - in part influenced by his mother Mary More - and situates them within the context of English image-making traditions and Waller's own natural philosophical interests. Examined as a functional whole, Waller's career as a Fellow of the Royal Society emerges as an important case study in the fusion of visual and scientific practices in early-modern England.

\footnotetext{
${ }^{1}$ Research for this paper was supported by the Arts and Humanities Research Council of the UK (grant AH/M001938/1). I am grateful for comments from an anonymous reader, Thomas Coleville, Sietske Fransen, Felicity Henderson, Alexander Marr, Noah Moxham, and Andrés Vélez Posada. I am especially grateful to Sachiko Kusukawa who generously shared with me her research, feedback, and expertise on Waller and the Royal Society.
} 


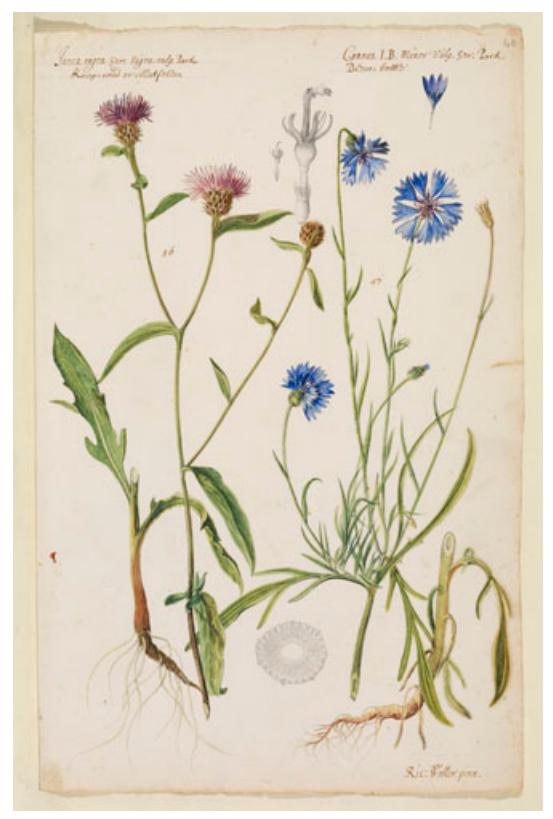

Figure 1: Richard Waller, Knap-weed or Matfelon and Cornflower or Bluebottle, 1689. Watercolor on paper. 380 x 240mm. London, Royal Society Archives, MS/131/040. (Photo The Royal Society)

Over the last years of the seventeenth century, natural philosopher Richard Waller undertook a study of English herbs and grasses through the creation of pictures. Using a technique called limning, he created a series of images, such as this knapweed and cornflower (fig. 1), detailing the unique features of each plant as he observed it with his eyes and with his microscope. In this image, Waller elegantly depicted both the delicacy of the semi-translucent blue petals, as well as the gnarled twists of the specimen's roots. Between the plant stems, he added additional visual information that cannot be so easily observed with the naked eye - magnified details drawn in pencil of the plant's interior. Waller deployed his graphic skill to create an image that is beautiful; at the same time he deployed his botanical knowledge to create an image that communicates scientific information. His picture is both a scientific and aesthetic object, and this combination calls for a re-evaluation of its creator. 
The name Richard Waller may not be instantly recognizable in its connection to the early Royal Society, but the images he produced for the Society are distinctive in terms of their quality, quantity, and diversity. As a Fellow from 1681 until his death in 1715, he performed diverse work on behalf of the Society: translating from Latin, French, and Italian into English; executing drawn, painted, and engraved images (by himself and collaboratively); researching and submitting scientific papers; and conducting a substantial portion of the Society's internal and external administrative affairs (fig. 2).

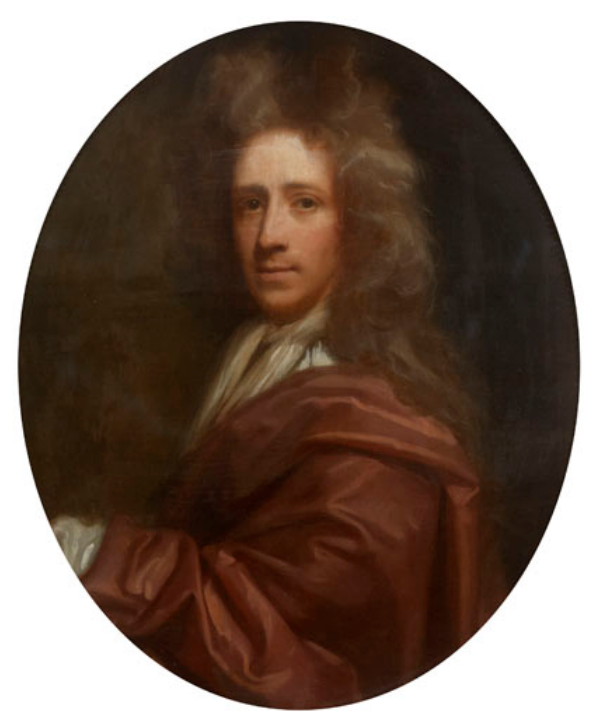

Figure 2: Thomas Murray, Portrait of Richard Waller, Eighteenth century. Oil on canvas. 754x632mm. Royal Society Collections (Photo The Royal Society).

Waller's visual productions were abundant and are acknowledged by scholars as some of the institution's most recognizable and striking. From exquisitely precise renderings of grass species to intricate allegorical frontispieces, Waller's contributions are some of the most colorful and distinctive images of the Royal Society's formative years. Their scientific content is diverse and sophisticated, and they exhibit a wide range of 
artistic skill and well-executed techniques. On behalf of the young scientific collective-of whom Waller was an important member-his images communicated both scientific ideas and more subtle, symbolic messages to peers, patrons, and the public. While many others - both Fellows and non-Fellows — created images for the Royal Society in the course of their research or administrative duties, Waller's were (and are) repeatedly distinguished by their scientific value, aesthetic qualities, and skillful execution. While Richard Waller has never been forgotten, the historical significance of his visual work and practices has yet to be examined systematically.

Waller's contributions, perhaps understandably, have been somewhat eclipsed by the bright ideas of his colleagues such as Robert Boyle and Isaac Newton. Historians have examined selected aspects of Waller's work, discussed below. Examined as a functional whole, however, his career as a Fellow of the Royal Society emerges as an important case study in the fusion of visual and scientific practices in early-modern England. I argue that Waller played a distinctly important role in shaping the visual program of the Royal Society by virtue of his multiple functions as reliable administrator and translator, competent natural philosopher, and skilled image-maker. I show how his graphic training — in part influenced by his mother, an artist — and educational preparation in natural philosophy endowed Waller with a unique combination of intellectual sensibilities and artistic skill that allowed him to create pictures that were both epistemically and representationally salient. It is no accident, I suggest, that both his peers and historians gravitated toward his visual productions as outstanding exemplars of the entangled nature of science and art that characterized the early-modern period. By analyzing a selection of Waller's works over his lifetime and across genres, I show how the distinctive interplay of 
his graphic training and his intellectual objectives operationalized and shaped the early Royal Society's visual culture. Waller's visual and scientific practices, moreover, also exemplify how image-creation - increasingly acknowledged by scholars to be a vital component of early-modern knowledge-making — was driven by skilled individuals, rather than institutional doctrine.

As a Fellow of the Royal Society, Waller's functions and products were recorded and are often mentioned in discussion about the institution. Critical examinations have been astute but uneven, and while scholars from literature to botany have analyzed aspects of Waller's work, he has been neglected by art historians. The majority of these studies then, have not considered him as an image-maker or the context of English visual traditions in this period. Margaret Ezell's biographical sketch of Waller pieces together what she describes as "fragments of a forgotten life" (Ezell 1984, 215). While informative, Ezell pays little attention to his graphic works. Felicity Henderson and Noah Moxham have looked at Waller as a translator and as the editor of Robert Hooke's posthumous works (Henderson 2013; 2017; Moxham 2016). Lawrence R. Griffing, on the other hand, scrutinizes Waller from the perspective of modern botany. Using his paintings of English herbs and grasses as a primary source, Griffing's concern is not historical, but rather how some of Waller's botanical ideas might have foreshadowed contemporary ones (Griffing 2011). To date, the fullest examination of his work is Sachiko Kusukawa's study of images produced jointly by Waller and the Society's Keeper of the Library and Repository, Henry Hunt, for the early Royal Society (Kusukawa 2011). Kusukawa shows how images and the processes of their creation emerged as a central component in the Royal Society's early collaborative investigations, and how Waller's contributions were 
integral to these processes. Kusukawa has also examined specific works by Waller, including his color chart and the fossil drawings by both Waller and Hooke (now in the Sloane Collection of the British Library), published in Hooke's posthumous works for which Waller served as editor (Kusukawa 2015; 2013). Building from Kusukawa's work on the significance of visual and collaborative processes within the Royal Society, this research examines the relationship between its visual and scientific practices by taking as a case study a diverse set of Richard Waller's works and his career as a Fellow.

This article seeks to better understand Richard Waller as an image-maker in the early Royal Society. First, I investigate Waller's educational and cultural background under the influence of his mother, the miniaturist Mary More, and in the context of English artistic traditions. Next, I scrutinize a selection of Waller's diverse visual works produced under the auspices of the Royal Society, to demonstrate how his scientific and artistic practices mutually reinforced each other. Finally, I analyze the two frontispieces he created for the Society in order to show how individual skill could drive practices in ways institutional doctrines did not. Taken together, these paint a fuller picture of a scientific and artistic life central to the seventeenth-century Royal Society.

\section{Waller's Cultural \& Educational Contexts}

Waller's cultural and educational experiences shaped the diverse contributions he would make to the collective work of the Royal Society. His considerable skills were acknowledged and valued by his colleagues. John Evelyn, a founding member of the Royal Society, recorded high praise for Waller in his diary: 
I went to visite Mr. Waller our Secretary, an extraordinary young Gent: \& of greate accomplishments: skild in Mathematics, Anatomie, Musick, Painting both in Oyle and Miniature to a great perfection, an excellent Botonist, Ingraves rarely in Brasse, writes Latine, \& is a poet, \& with all this exceedingly modest: His house is an Academy of it selfe (De Beer 1955, 175; Ezell 1984, 219; Ezell 1987, 146).

For Evelyn, Waller's ability to paint in oil and miniature, were as notable as his expertise in botany. The range and level of Waller's skills, however, stand out to such a degree that their acquisition cannot be attributed solely to conventional cultural or class-based educational standards for males of his birth (Bermingham 2000; Sloan 2000). There is compelling but incomplete evidence to indicate that the differentiating factor was the influence of Waller's mother on his intellectual and artistic development.

Waller's exact birth year is uncertain and little is known of his early life. Indeed, until recently he had been mistaken for another man named Waller who attended Cambridge University (Ezell 1984, 216). ${ }^{2}$ Our Waller's father, also Richard Waller, died sometime late in 1662. His mother, Mary Waller (née Tyther), was remarried to Francis More on 7 October 1663 and became Mary More (or Moore). ${ }^{3}$ Tax and inventory records

\footnotetext{
${ }^{2}$ The literature and records on Waller seem to variously give his birthday year as circa either 1646 or 1660 . Given his sister was born in 1663 and his juvenile portrait is from the mid-1670s, I incline to think Waller was born closer to 1660 .

${ }^{3}$ This account of the Waller and More families is based on unpublished biographical research done by Sachiko Kusukawa, and Ezell and Teague 2016, 99-101.
} 
indicate the family was wealthy and prosperous, and Richard would have grown up in a life of comfort. In 1685, Waller married Anne Blackwell, and they went on to have three children, none of whom survived him. He had one younger sister, Elizabeth, who in 1680 married Waller's friend and colleague at the Royal Society Alexander Pitfield. The Mores, Wallers, and Pitfields lived near each other in London, and they frequently saw each other and even transacted business between themselves (Teague and Ezell 2016, 101). The family estate at Northaw in Hertfordshire, which Waller inherited from his grandmother through his mother, would become a second residence for Waller towards the end of the century.

Little is known of Waller's artistic education, other than the very suggestive fact that his mother Mary More was a miniaturist and painter. As with Waller, practically nothing is known about Mary More's artistic background or training but Margaret Ezell speculates that she was likely the beneficiary of parents who offered their daughters educational opportunities, sending her to one of the private ladies' academies, or educating her at home by an erudite relative (Ezell 1987, 147). In whatever form she was educated, we know that by her adulthood Mary More had obtained skills in rendering portraits, and had facility with several languages including Latin and Greek.

The unknown details of Mary More's life are compounded by the very scant traces that remain of her artistic works. In his Anecdotes of Painting in England (1762), Horace Walpole described Mary More as: 
A lady, who I believe painted for her amusement, was the grandmother of Mr. Pitfield; in the family are her and her husband's portraits by herself. In the Bodleian Library at Oxford is a picture by her that she gave to it, which by a strange mistake is called Sir Thomas More, though it is evidently a copy of Cromwell earl of Essex. Nay, Robert Whitehall, a poetaster, wrote verses to her in 1674 , on her sending this supposed picture of Sir Thomas More (Walpole 1762, 3:135-36; Ezell 1987, 144).

That Walpole includes More in his Anecdotes means he perceived her as more than a dilettante painter, yet the fact that only one of her works survive means very little else is known, or has been said, about her art. The painting Walpole referred to, donated to the Bodleian Library in Oxford in 1674, is the only known surviving work definitely attributable to More (fig. 3). ${ }^{4}$ The painting is of Thomas Cromwell, Earl of Sussex after the portrait by Hans Holbein, though at the time it was erroneously identified as Sir Thomas More. ${ }^{5}$ The painting demonstrates Mary More's facility in painting, though it has been heavily restored so it is difficult to make out unique features of her hand. The fate of her other works, or why she decided to gift this particular painting to Oxford, remain a mystery.

\footnotetext{
${ }^{4}$ Bodleian Library, Oxford University, 1674, accession number LP 27.

${ }^{5}$ Robert Whitehall made this claim in 1674 in his poem to Mary More: "No Less Virtuous Than Ingenious Mris Mary More; upon her Sending Sr Thomas More's Picture (of her own drawing) to the Long Gallery at the Publick Schools in Oxon," in the British Library, Harley MS 3928, 59r. Also published in Ezell 1987, 148-9.
} 


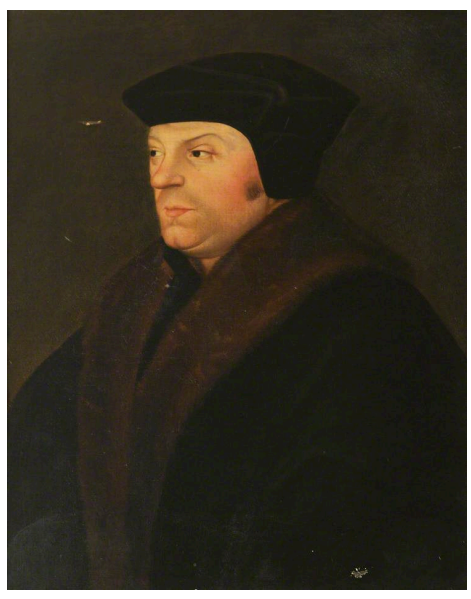

Figure 3: Mary More, Portrait of Thomas Cromwell, Earl of Sussex, 1674. Oil on canvas. 603 x $483 \mathrm{~mm}$. LP 27, Oxford, Bodleian Library, LP 27 (Photo Bodleian Library Oxford)

Though not a professional artist, Mary More's artistic work, particularly in miniatures, situates her in a distinctly English artistic tradition. Though portrait miniatures were created throughout Europe, they gained particular popularity in post-Reformation England and gained demand in the Elizabethan court (Golding 2019, 1-3; Murdoch, Murrell, Noon, and Strong 1981; Strong 1983). In contrast to public oil portraits, miniatures were intimate objects, often no larger than a watch face, and intended for close viewing. The most famous English miniaturist, Nicholas Hilliard, created portraits for nobles and monarchs, and he also wrote an unpublished manuscript promoting the art and its technique, known as A Treatise Concerning the Arte of Limning (c.1600) (Golding 2019, 1; Faraday 2019, 137; Coombs and Derbyshire 2015; Leonhard 2015). While miniatures were popular throughout English society, it was a genre seen as acceptable for and associated with women. Linked with display in intimate, domestic spaces, miniatures were collected, and sometimes created by women, most famously Levinia Teerlinc, an active limner at the English court in the mid-sixteenth century, who may have trained Hilliard (Goldring 2019, 75). Thus, unlike other artistic forms and genres, miniature 
painting was a more accessible art form for women, and one that would have given Mary More specific techniques and elements of an English visual vocabulary that we will see later in her son's works. ${ }^{6}$

As a portraitist and miniaturist, More would have been well versed in the art of limning. This technique, particularly deployed for miniature portraits, involved a form of watercolor painting where pigment was mixed with gum in different proportions to create matte, saturate colors (Coombs and Derbyshire 2015, 242; Murdoch, Murrell, Noon, and Strong 1981, 3; Leonhard 2015). Seen as a particularly English art form, miniature painting and limning was championed in several treatises. A generation after Hilliard, interest in the technique was still high, and Edward Norgate's Miniature or the Art of Limning circulated in virtuosi circles (Norgate 1997, 12-20). Published in 1627/8 with a revised second edition in 1648, Norgate's text details the art form's materials and techniques. He explains in the outset of his treatise that, as a limner, "[t]o proceed then you must know that there is nothing more requisite in this excellent Art (next after the Study of Designe and Drawing which worthily takes up the fist and principall place and whereof it is not now my part nore purpose to speake) Then is the true order and manner of the Colours, the meanes to prepare them ready for the pencil and to cleanse them from those grosse and corrupt mixtures and faeces, where with by the art and avarice of those that sell them or the carelessness of those that make them, they commonly are sophisticated" (Norgate 1997, 58-9).

\footnotetext{
${ }^{6}$ For more on the wider context of early-modern English art and architecture see Hallett, Llewellyn, and Myrone 2016; Hanson 2009; and Hunter 2013.
} 
For Norgate, knowledge of colors and their application is central (and knowledge of drawing is so inherent a necessary skill, he assumes it of the practitioner). As we will see, Richard Waller similarly developed an acute interest in and sensitivity to color. Though we do not know of any miniatures he executed, Waller favored limning as a technique for the images he created in the pursuit of natural philosophy.

Though Mary More is remembered as an artist of works that do not survive, a treatise she wrote has been preserved in the British Library. ${ }^{7}$ Titled "The Womens Right," More's treatise argues for women's greater equality to their husbands in England, particularly in the context of marriage. Written in the 1670s, More addressed the manuscript to her young daughter, Elizabeth Waller, and the preface gives her prescription to her daughter for achieving equality in marriage. Her motivation to write the text, she says, came not from unhappy marriages of her own, but rather from:

observing the sad consequences \& events that have fallen on men and their Wives, through this mistake of mens pretending a Power over their Wives, that neither God nor nature doe allow, and I dare be confident that if any unbiased person observe it, they must conclude this to bee the first and great cause of most breaches between men and their Wives. ${ }^{8}$

\footnotetext{
${ }^{7}$ Mary More, “The Womans Right Or Her Power in a Greater Equality to her Husband proved than is allowed or practised in England," the British Library, Harley MS 3918, 46r58r. Editions have been published by Ezell 1987 and Teague and Ezell 2016.

${ }^{8}$ British Library, Harley MS 3918, 46r-58r; also reprinted in Ezell 1987, 192-93.
} 
The body of the text addresses the relationship between the sexes, and the biblical mandates for equality and partnership in marriage. The text remained unpublished in More's lifetime, however Robert Whitehall, a poet and Oxford don, refuted More's text with one of his own entitled "The Womans Right Proved False."9

Geography and family connections placed Mary More at the periphery of the social and intellectual circles of the Royal Society. After the fire of London, she lived at Crosby Square in Bishopsgate, not far from the Royal Society’s meeting place at Gresham College. Both her son Richard Waller, and son-in-law Alexander Pitfield were fellows of the Royal Society, and she was in Robert Hooke's acquaintance as well. In his diary, Hooke mentions several times meeting Mrs. More for tea, checking on her during illness, discussing Greek with her, eating cheesecake, and even borrowing her china. (Gunther $1935,83,102,120,122,128-9,163,191,219,230,234,246,252,256) .{ }^{10}$

Waller's early exposure to drawing and limning through his mother would have been compounded by the prevalence and promotion of drawing in his social and intellectual spheres. Drawing was considered a worthy skill for a gentleman, and many etiquette guides published in England at the time discussed the value of obtaining this skill. In 1622, Henry Peacham published The Compleat Gentlemen, which set out to describe and explain the corpus of knowledge and set of skills a gentleman of refinement

\footnotetext{
${ }^{9}$ British Library, Harley MS 3918, fols. 2r-45v.

${ }^{10}$ I am grateful to Felicity Henderson for allowing me to consult a copy of her forthcoming edition of the Diary of Robert Hooke.
} 
and standing must possess. ${ }^{11}$ Following in a tradition of courtesy literature, The Compleat Gentleman describes both the education a young noble should receive, and also the subjects in which they should be well versed. In addition to geometry, poetry, war, and fishing, Peacham also singles out drawing and painting in oil as necessary skills. The Compleat Gentleman was extremely successful, going through several reprints and subsequent editions in the 1620 s and 30 s. Peacham states that drawing was "a quality most commendable, and so many wayes usefull to a Gentleman" (Peacham 1634, 124). As he explains, a gentleman may find drawing useful in wartime to describe a fortification, battalion formation, or geographic location; vital for mathematical demonstrations; and drawing enables the gentleman to record the sights and experiences from travels abroad. Drawing is even the mechanism to preserve the memory of a "dearest friend or fairest mistresse" (Peacham 1634, 125). Drawing then was not just an amusing pastime, but had utilitarian benefit to men of a certain station. It is clear to see that the reasons drawing would be useful to a gentleman could also apply to the natural philosopher.

In accurately rendering a specimen for study or a diagram to a mathematical proof, the virtuosi of the Royal Society used drawing in service to the study of nature. The prevalence of drawing within Waller's milieu, can be seen through the many drawing manuals that circulated within the Royal Society, and Waller himself is known to have

\footnotetext{
${ }^{11}$ The book's long subtitle is: The Compleat Gentleman: Fashioning him absolut in the most necessary and commendable qualities concerning mind or body, that may be required in a noble gentleman.
} 
owned many books related to the arts. ${ }^{12}$ Though Peacham's was among the earliest in date, many other publications promoted the value of artistic skill or the details of a specific artistic technique. Case in point, the Royal Society owned a manuscript copy of Edward Norgate's Miniatura or the Art of Limning, and it remains in the archives. ${ }^{13}$ As Sachiko Kusukawa emphasizes in her introduction to this special issue, many Royal Society members themselves engaged with this literature (Kusukawa 2019). John Evelyn translated the French text An Idea of the Perfection of Painting by Roland Fréart, and in 1662 published his own text on engraving, Sculptura: or the History and Art of Chalcography and Engraving in Copper, which gave broad instructions in how to pursue copperplate engraving as well as an account of the great masters of the art. From the outset, Evelyn saw these skills as useful to the natural philosopher. In addition to being dedicated to his Royal Society colleague Robert Boyle, Evelyn made clear these skills would be useful as those "as are addicted to the more Noble Mathematical Sciences, may draw, and engrave their Schemes with delight and assurance" (Evelyn 1662, 2). In addition to providing a history of different engraving practices, Evelyn's text also introduced the mezzotint technique to England on behalf of his Royal Society colleague, Prince Rupert. ${ }^{14}$

The Fellows of the Royal Society frequently employed, discussed, and debated artistic practices. Many drew themselves, but even those who did not would have

\footnotetext{
${ }^{12}$ Waller's library contained a copy of John Bate's The Mysteries of Nature and Art, Joseph Moxon, Practical Perspective, and William Aglionby's Painting Illustrated in Three Dialogues. I thank Sachiko Kusukawa for calling this to my attention.

${ }^{13}$ Royal Society Archives, MS/136.

${ }^{14}$ For more on the introduction of mezzotint to Britain, see Thomas 2010.
} 
encountered the drawing manuals in the Society's library, discussed new graphic techniques (such as mezzotint) when they were presented to the Society, and debated the merits of specific depictions and techniques. Waller's good friend Robert Hooke apprenticed with the painter Peter Lely and was an accomplished image-maker (Henderson 2019). A manuscript copy of Edward Norgates Miniatura circulated in the Royal Society, while in 1667 Thomas Povey presented a paper on a secret used in painting before the assembled Fellows. ${ }^{15}$ Thus, drawing and artistic techniques were not crafts restricted to the domain of professional artists and artisans, but were practices the Fellows would have frequently encountered in their social and scientific lives. It is in this context of drawing as a social and also increasingly a scientific practice that we must view Waller and his work.

\section{Waller's Juvenalia}

The earliest known examples of Waller's graphic work are the illustrations from a manuscript translation by Waller of Maffeo Vegio's additional book to Virgil's Aeneid (Fig. 4 \& 5). ${ }^{16}$ Completed 1674-76, these drawings are the earliest known works by Waller. The text includes eleven full-page, ink and grey-wash illustrations depicting

${ }^{15}$ [Thomas Povey] "An Account of A Secret in the Use of Painting in Answer to the Command of the R. Society Brought in by Mr. Povey, and read before the Society Dec. 19, 1667,” Royal Society Archives, Register Book Original, vol. 3, fols. 259-64. This text is also reproduced in Birch 2:227-30 and is discussed in Hunter 2013, 98-100.

${ }^{16}$ British Library, Add. MS 27347. 
various scenes from the narrative. Though Waller's rendering of the classical figures is a bit clumsy in places, as a whole his images are well composed and show his skills in rendering drapery, shading, and depth. For instance, his title image (Fig. 4) depicts a complex scene of allegorical figures, landscape background, and calligraphic text. In a few places the faces of figures appear a bit blunt or out of proportion, but as a whole the image is a decent rendering of a complex scene. The work is clearly by an amateur, but demonstrates a good deal of youthful talent.

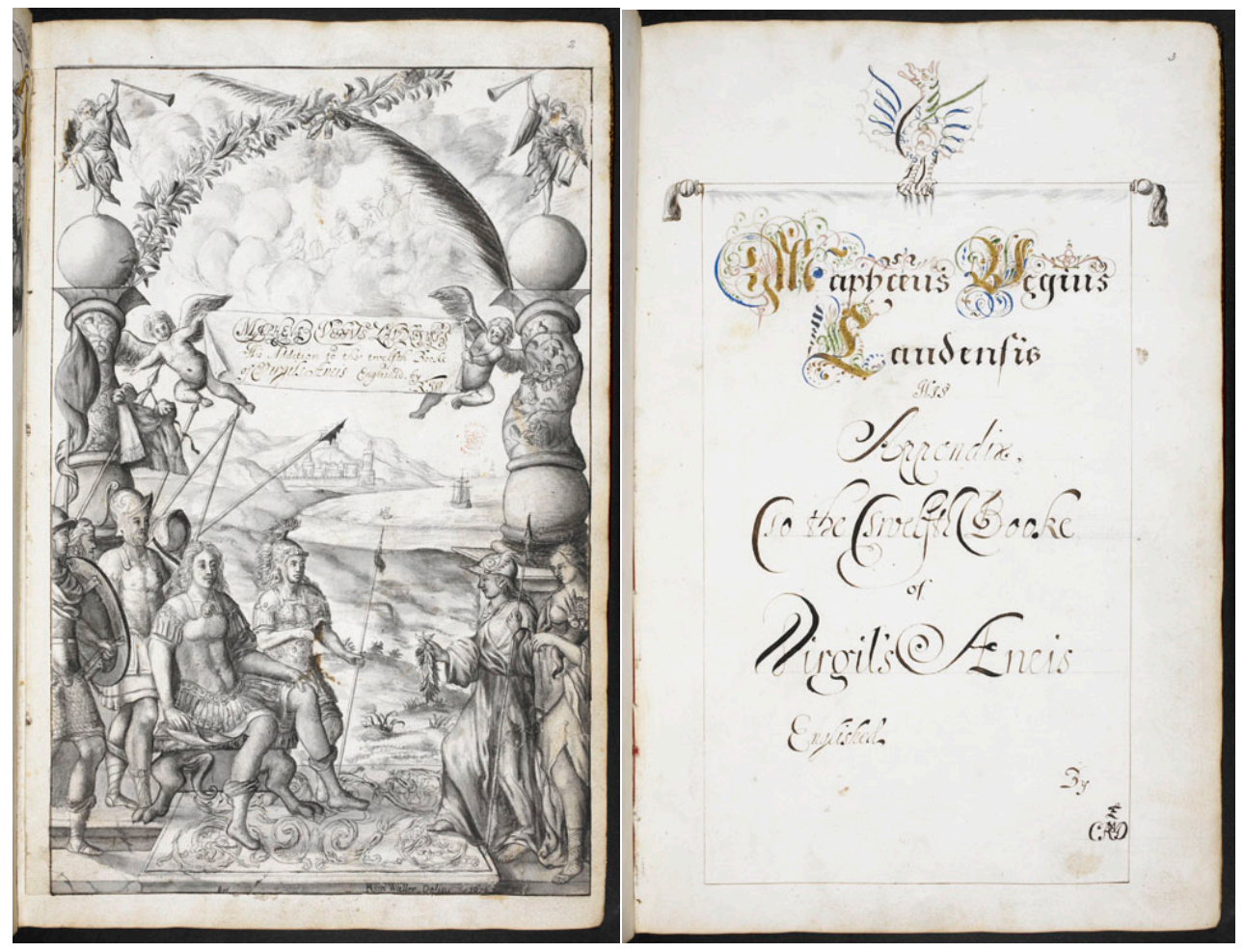

Figures 4 \& 5: Richard Waller, Title pages to "Maphaeus Vegius Laudensis, His Addition to the twelfth Book of Virgils Aeneis. Englished By R[ichard. W[aller]," 1674-76. Ink, wash, and pencil on paper. London, The British Library, MS Add. 27347, 2r \& 3r. (Photos The British Library) 
Scholars have suggested Waller based his engravings on the ones by Wencaslaus Hollar from the translated and published works of Maffeo Vegio by John Ogilby from 1654 (Ezell 1984, 217). Despite the stylistic similarity (and Waller's choice of medium mimics the grey and white tones of the engraved images in Ogilby's book), Waller's images depict different scenes and views from the story. Thus, though Waller's illustrations might have been inspired or influenced by Hollar's images in Ogilby's edition, they are far from direct copies. Instead, Waller drew from a collage of visual and calligraphic influences to create these illustrations.

Notwithstanding the uncertainty of Waller's exact age when executing this series (as his date of birth has still not been definitively determined), the portrait of Waller on the first page looks decidedly youthful (fig. 6). In the portrait, the young Waller is depicted in a simple smock, looking at his audience, his image in a wreath roundel hanging from a garland. Two small putti figures sit astride the garland, which bears multiple fruits, and Waller's Latinized name appears below. The picture is entirely monochrome grey-wash save for a few touches of gilding used to highlight the ribbon running throughout the picture. These features echo visual motifs common in portrait miniatures; the roundel evokes the small size and shape of a miniature while gold accents were also frequently used (Coombs and Derbyshire 2015, 249-51). Margaret Ezell attributes the portrait to Mary More, not Waller, as it is unsigned, unlike the other illustrations (Ezell 1984, 148). However, the style of the figure combined with the consistent decorative motifs and writing in Waller's hand leads me to conclude this was almost certainly a self-portrait. 


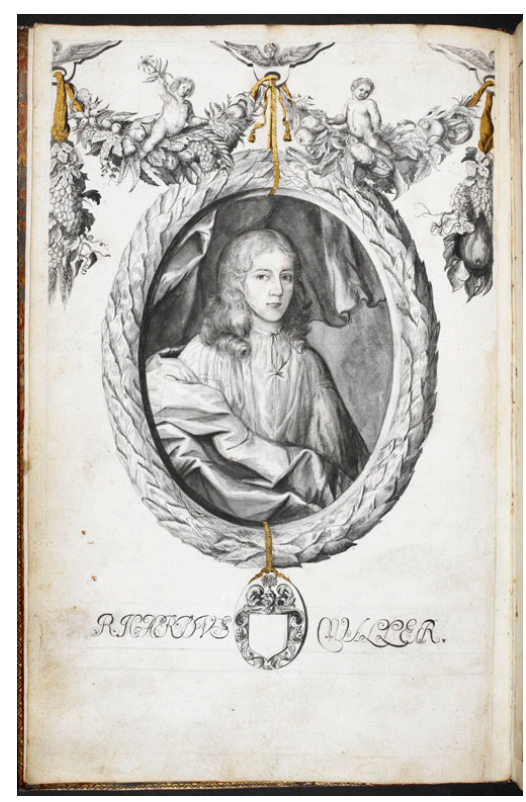

Figure 6: Richard Waller, Self-Portrait from "Maphaeus Vegius Laudensis, His Addition to the twelfth Book of Virgils Aeneis. Englished By R[ichard. W[aller]," 1674-76. Ink, wash, and pencil on paper, with gilding. London, The British Library, MS Add. 27347, 1v. (Photos The British Library)

Other aspects of Waller's Virgil edition further highlight his skill and interest in calligraphy. Between the full-page drawings illustrating the volume, Waller adorned the pages of text with calligraphic flourishes. Many of these are very elaborate, taking the form of real and imaginary animals, birds, dragons, and cupids. Drawn in red, yellow, blue, and green ink, these whimsical creatures provide judicious splashes of color amid the monochrome images. The final page contains some of the largest examples - a golden lion and rearing unicorn face off under the final lines of prose, while two putti herald the end of the text with a trumpet and garland (fig. 7). Waller copied many of these designs from Edward Cocker's Copy book of Pemanship (1664) (Kusukawa 2015, 5). Waller specifically draws from Cocker's frontispiece: he includes his own portrait in a wreath roundel in the same fashion and pose as Cocker's own portrait, and the two calligraphic 
putti above Cocker's portrait appear on Waller's final page. The two figures, brandishing a wreath, appear in reverse from Cocker's frontispiece, indicating Waller might have traced them (fig. 8). These calligraphic figures require a discipline and control of the hand skills Waller would deploy during his secretarial work for the Royal Society.
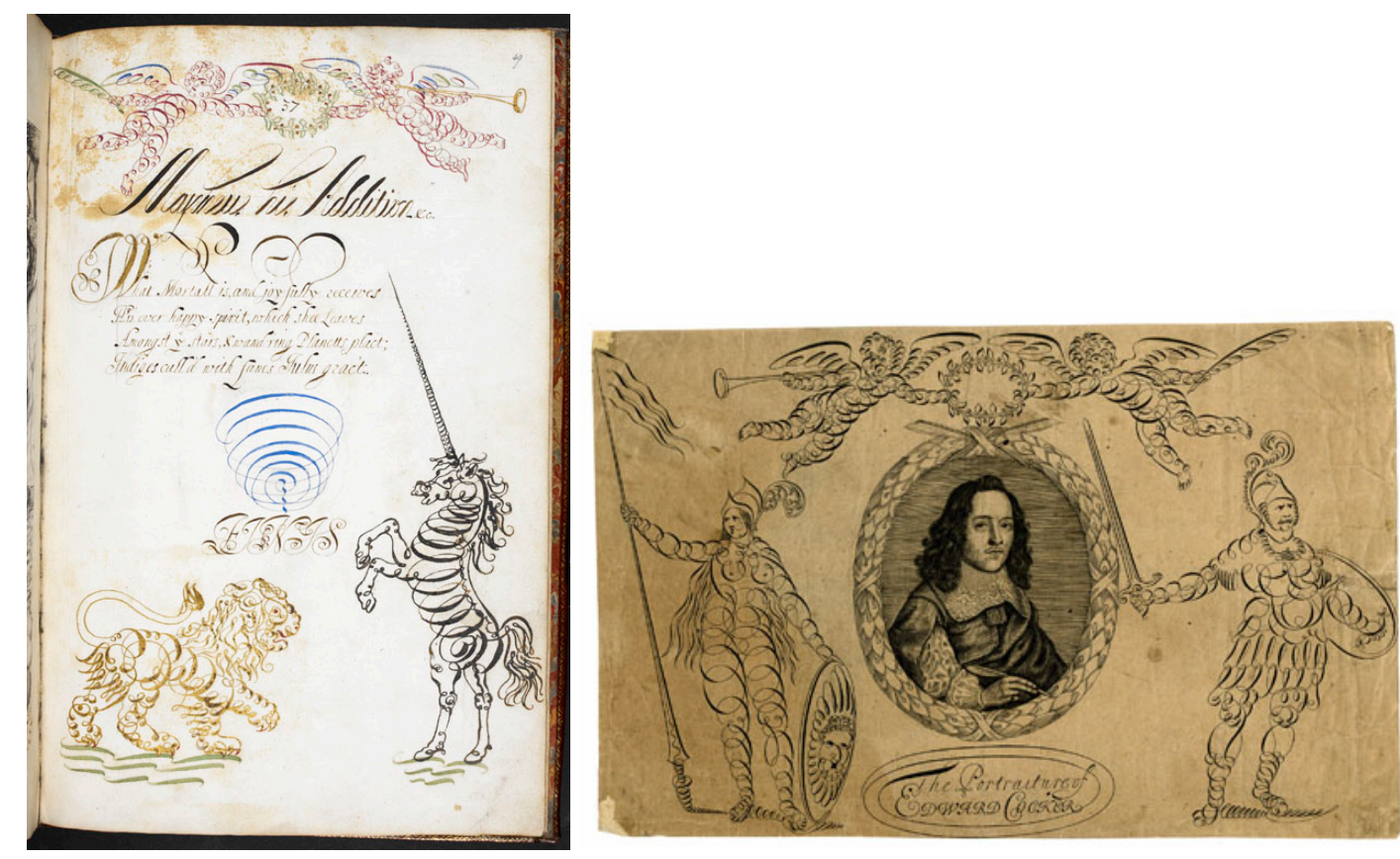

Figure 7 (Left): Richard Waller, Last page to "Maphaeus Vegius Laudensis, His Addition to the twelfth Book of Virgils Aeneis. Englished By R[ichard. W[aller],” 1674-76. Ink and pencil on paper, with gilding. London, The British Library, MS Add. 27347, 49r. (Photos The British Library)

Figure 8 (Right): Edward Cocker, The Portraiture of Edward Cocker from the Copy book of Penmanship, 1664. Ink on paper, engraving. 190 x 298mm. The British Museum (Photo The British Museum)

In many ways this volume highlights Waller's early visual focus, while also foreshadowing his future work for the Royal Society. Waller's Aeneid addition was never published and some of the illustrations are unfinished, but nevertheless it shows his 
already developed interest and skill in translation as well as his abilities in drawing and calligraphy. Though much of Waller's early life remains a mystery, it is likely that he received artistic training from his mother, as encouraged by his social milieu, and he seems to have particularly taken to the English art of limning. It is when Waller joins the Royal Society that we see his artistic skills applied to his natural philosophical interests.

Waller \& The Royal Society - Epistemic Images and Artistic Motivations

As a member of the young Royal Society, Waller entwined his artistic interests and skills with his intellectual curiosity and epistemic questions. It was during his time as part of the Royal Society that Waller executed most of his known graphic works. Elected a Fellow in 1681, Waller would further serve the Society as Secretary from 1687 to 1714 , and as Vice President in 1709. Through his various roles, Waller continuously engaged with the visual practice of natural philosophy. In fact, after his election in April, Waller's first act as a Fellow brought his graphic skills to the Society's attention. At the meeting of 9 November 1681 ,

Mr Richard Waller presented a picture of Dr Goddard, drawn by Mr Waller himself on memory, after the death of Dr Goddard. It being viewed by those, who were present, and knew the doctor, was judged to resemble him in many particulars, and ordered to be carefully kept with the other pictures of the fellows of the Society (Birch 1756, 4:100-01). 
Waller's portrait of Goddard has now been lost, but its existence indicates that to some degree he continued the figurative image-making begun in his youth, and that his portrait was of sufficient quality to be kept in the Society's collection.

Over the decades of his membership Waller did very different types of work, ranging from scientific investigations to administrative and organizational tasks. These included image-making assignments, such as when the Fellows desired for Waller "to design the figure of the salt, as it appeared in the microscope" or other such rendering (Birch 1756, 4:443).

These tasks increased during his tenure as Secretary. Waller's friend Robert Hooke seems to have encouraged him to step into an organizational role, writing in his diary: “told Wallr of joyning for secretary" (Gunther 1935, 101). In addition to keeping the Society's minutes, correspondence, and compiling the Philosophical Transactions, Waller's duties as Secretary were varied, and the Society's administrative papers record him being asked to perform additional tasks from making images to auditing the treasurer's accounts or creating an index for the journal books (Birch 1756, 4:443, 463, $516,551,557)$. Though he remained an active and involved member of the Society throughout his term, his administrative duties seem to have been an increasing burden, and he had a growing uncertainty that he could meet their demands. Throughout the 1690s and 1700s Waller wrote many letters to then Secretary Hans Sloane asking for another "fitter" person to be found to take over the role. ${ }^{17}$

\footnotetext{
${ }^{17}$ British Library, Sloane MS 4036, fol. 194r; Sloane MS 4041, fol. 79r. There were usually two Secretaries at one time.
} 
In 1694, writing to Sloane from Northaw after missing him in London, Waller pleaded for Sloane to find another person for Secretary. He explained:

my living so very much in the country, as I have of late, makes me uncapable of doing that service which affection for the R.S. would easily engage me in; so that I find it very difficult, indeed impossible to come off with honour or satisfaction to my selfe or others in the duty I think my selfe obliged to. ${ }^{18}$

On the chance Sloane thought he was being modest, he went on to emphasize, "Sir I am real in this, tis not nolo Episcopari." ${ }^{19}$ Waller uses this phrase, associated with false modesty, to make his claim emphatic. Yet ultimately either his plea fell on deaf ears or no suitable replacement volunteered, as Waller was re-elected Secretary shortly thereafter.

Despite his reluctance to continue as Secretary, frequent complaints to Sloane, and largely residing outside of London, Waller remained an active member of the Society in many capacities. The minutes and records of the Royal Society record that Waller was frequently involved either in putting forth a scientific paper or idea or in creating an image to record or preserve a finding. These two roles of Waller's - as scientist and imagemaker - seem to have gone seamlessly hand in hand. For Waller, making images was a central part of his scientific work. This was also true for the Royal Society at large, and

\footnotetext{
${ }^{18}$ British Library, Sloane MS 4036, 26 November 1694, fol. 194r.

${ }^{19}$ This phrase allegedly was used by clerics to decline the role of bishop (literally "I do not want to be bishop"), which was done out of modesty before actual appointment. The phrase has come to be used as a false modesty for something that is actually desired. Ibid.
} 
Waller frequently made images outside of his own work for the benefit of the Society as a whole.

For Waller, as with many of his contemporaries, there were no hard boundaries between his practice as an image-maker and his practice as a natural philosopher, and these two realms of skill often influenced and informed one another. His artistic skills were frequently put into service to facilitate the acquisition of knowledge, and his scientific questions were influenced in part by his visual thinking.

The Art of Color

One of these points of intersection was Waller's scientific interest in, and artistic use of, color. In 1685 Waller's study and illustrations of the Cicindela Volans or Flying Glowworm were published in the Philosophical Transactions (fig. 9). Waller observed the rare insect over several years from his country home in Hertfordshire, and his illustrations of the insect and its parts observed through the microscope were also published in the journal. Yet, though Michael Burgher's engraved images of Waller's drawings were necessarily black and white in print, Waller includes vivid descriptions of the insect's color in his account. He describes the insect's head covering as "speckled brown and yellowish colour, like Tortois shell," while the thorax is "a Polisht copper colour" (Philosophical Transactions 1685, 844). Waller's artistic training did not give him an exclusive concern for color, but it may have made him more sensitive to subtle fluctuations in color as well as its importance in the natural world. 


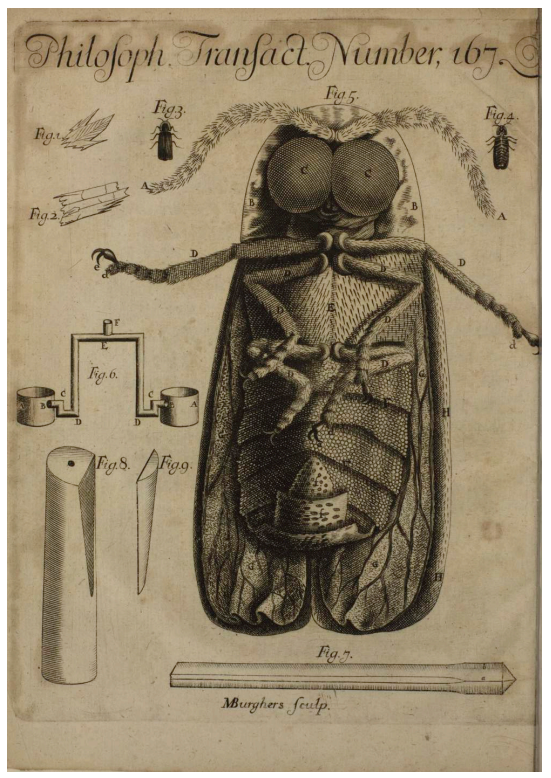

Figure 9: Michael Burgher after Richard Waller, "Observations on the Cicindela Volans, or Flying Glowworm, with the figure thereof made, and Designed by Richard Waller Esq. of the R.S." Figures 1-9, Philosophical Transactions vol. 15, 1685. Ink on paper, engraving. London, Royal Society Archives (Photo The Royal Society)

Waller's interest in color extended to how color was manifest in other aspects of the natural world. In 1688 one of Waller's parakeets died. Waller took advantage of the situation and used his dead pet for an anatomical investigation. First, Waller made a thorough description of the parrot's exterior form, and he emphasized the bird's extraordinary colors, as "luxuriant nature paint[ed] him with all the silken colours of plants and flowers." ${ }^{20}$ After describing the bird's features he focused in depth on one single quill:

of a lemmon colour inclining to a green, next that a scarlet for a pretty breadth then a narrow thread of green on some of them, after that a black and last of all ending in a

${ }^{20}$ Royal Society Archives, Classified Papers 15i/37. 
light green. It were not an unworthy curiosity to examine the colours of the feathers of Birds and how the same individual branch of the stemm of a feather as here comes to be tinged with such diversity of colours. ${ }^{21}$

Alongside his textual description, Waller drew several anatomical features of the bird from his dissection, including the elaborate quill (fig. 10). Waller's visual training might have made him more attentive to the subtle variation in color in a single feather and caused him to question why that would occur. Waller used color in some form in almost every image he made. But rather than an unconsidered artistic tool, as a natural philosopher he questioned how colors were composed, varied, and manifest in nature.

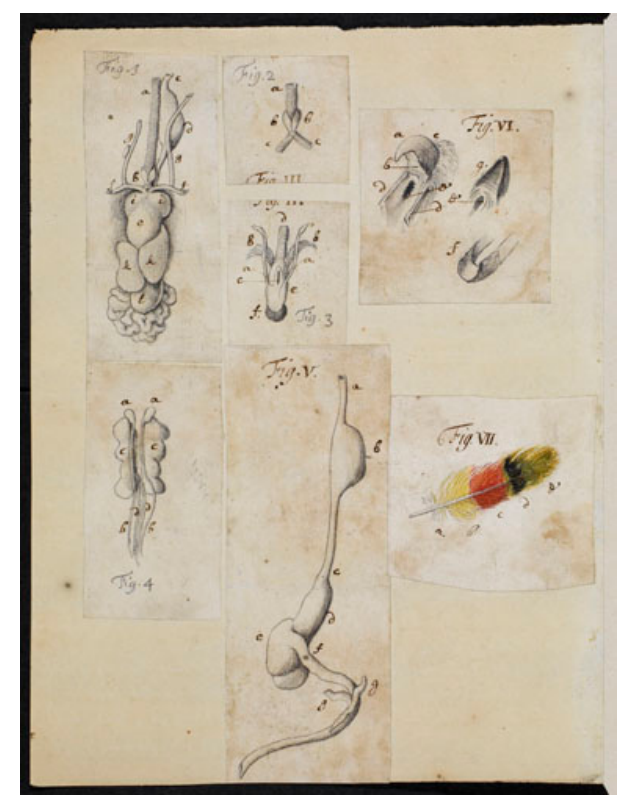

Figure 10: Richard Waller, Dissection of a Parakeet, 5 December 1688. 202 x 150mm. Body color, ink, pencil, and wash on paper. London, Royal Society Archives, Cl.P/15i/37/004. (Photo The Royal Society)

21 Ibid. 
Waller's interest in color persisted and extended into a more systematic study. Sometime prior to February 1686, Waller created a catalogue of colors, which he was reminded of during a discussion of mineral ores applied to glass at a meeting of the Royal Society. At the meeting the following week, on 17 February 1686, Waller "presented his table of colours neatly drawn with his own hand" (Birch 1756, 4:459; Kusukawa 2011; 2015). The Fellows approved, and "[i]t was ordered to be put in a frame with a glass before it to be hung up in the Society's meeting room." Clearly the Fellows found Waller's catalogue not only informative but significant and visually appealing enough to be hung in their most public space. Possibly spurred by this encouragement, the following month Waller again brought in a "scheme of colours" this one showing various mixtures of yellows and blacks, which "produced a series or shade of most colours imaginable" (Birch $1756,4: 471)$. As an image-maker, Waller was interested in color and its application. He continued working on the subject, developing a "contrivance for printing of colours" through a series of "small taper pipes" which could be variously opened and closed to allow the right blend of pigments to be applied on the page (Birch 1756, 4:480). When Waller's color chart was printed in the Philosophical Transactions in 1686, and each color added to it by hand through the mixing pipes, it became the first instance of color used in the journal (fig. 9). Waller's table of colors was not merely an artistic curiosity; as Sachiko Kusukawa has shown, it was Waller's attempt to provide a standardized reference for natural philosophical purposes (Kusukawa 2015, 17-18). Given the centrality of verbal and visual description for new observations, experiments, and discoveries in this period, the desire to provide a common color reference would help facilitate communication. As 
Secretary, Waller would have received and sent a great deal of correspondence on behalf of the Society, and thus been aware how greatly descriptions and uses of color could vary.

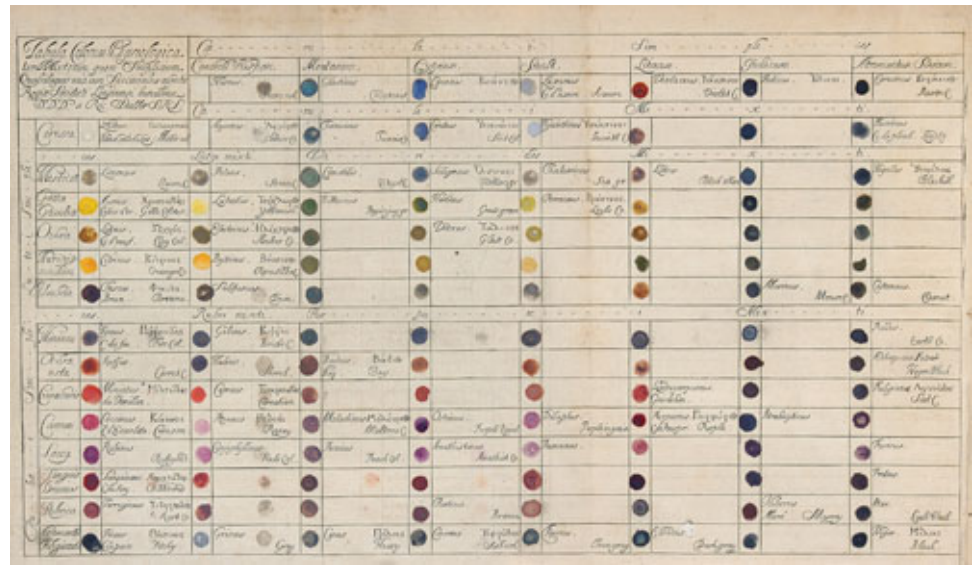

Figure 11: Richard Waller's Color Chart in “Tabula colorum physiologica tam mixtorum quam simplicium quadrilinguis una cum speciminibus adjectis" Philosophical Transactions, vo. 16, 1686. Pigment and ink on paper. London, Royal Society Archives (Photo The Royal Society)

Nature Observed

Like many of his peers, Waller relied on images to communicate his scientific findings, and creating images to accompany his texts was central to the process of his own natural philosophical investigations. In his paper read before the Royal Society on 27 March 1689, Waller described his investigation of a scorpion from Barbary with two eyes in the middle of its back:

Examining these with a good Microscope I could not discover them to consist of several Hemispheres as those of flyes and the like do which I have often seen by a much worse glass then what I now made use of and if they are so formed which I am 
apt to thinke they not being movable they are of extream small spheres. The Eyes are represented larger in the $2^{\text {nd }}$ fig. ${ }^{22}$

His description goes on to describe and analyze the scorpion's tail and stinger, for which he also includes a drawing "as the microscope represents it" (fig. 11). In addition to describing and depicting the scorpion and the enlarged views of its unique features, Waller compares the claws on the animal to those described in Francesco Redi's book on the generation of insects (Redi 1671). Waller's limned drawings call attention to details of the animal's features, which allow them to be compared to those of other species.

In a similar fashion, Waller drafted an image series recording his observations and experiments on tadpoles. In March of 1689, having collected some tadpoles from a ditch, Waller observed their development and growth over several days, making figures of them and having them "represented bigger then the life, that the posture they lay in may be seen the better. ${ }^{, 23}$ His images record the subtle changes in the tadpoles over time, noting when different morphological features can be viewed, as when "some rudiments of their fore legs were visible which looked forked \& like a sprig of a plant." Here Waller uses the technique of "zooming in" to call attention to the smallest detail. ${ }^{24}$ Waller would have seen this style of microscopic close-up in his friend Hooke's Micrographia (1665). These images not only record the ephemeral moments of Waller's research (moments in tadpole

\footnotetext{
${ }^{22}$ Royal Society Archives, Classified Papers 15i/38.

${ }^{23}$ Royal Society Archives, Classified Papers 15i/40.

${ }^{24}$ For more on the manipulation of images and "zoom" technique in the sixteenth and seventeenth centuries, see Egmond 2017.
} 
development, for instance), but also communicate observations difficult, or impossible, to see with the naked eye. In this example, Waller's drawings enabled him to compare all of the tadpole stages in one view, a comparative analysis only possible with the aid of his drawings. $^{25}$

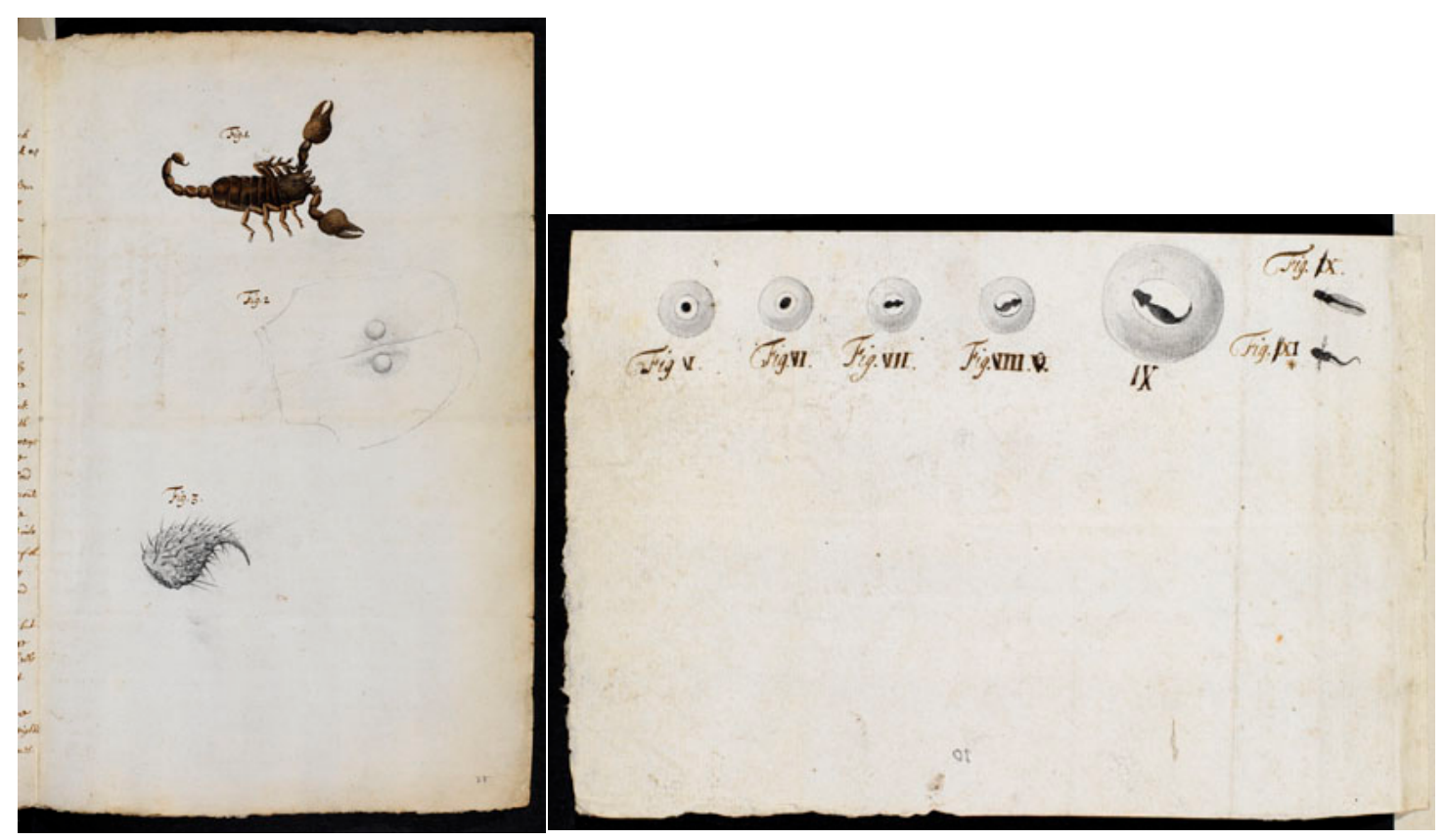

Figure 12 (Left): Richard Waller, Scorpion from Barbary, 27 March 1689. 333 x $211 \mathrm{~mm}$. Body color, ink, pencil, and wash on paper. London, Royal Society Archives, Cl.P/15i/38/003. (Photo The Royal Society)

Figure 13 (Right): Richard Waller, Spawning of Tadpoles, 17 December 1690. 123 x 187mm. Ink, pencil, and wash on paper. London, Royal Society Archives, Cl.P/15i/40/002. (Photo The Royal Society)

${ }^{25}$ Stages of tadpole and embryo development were also observed and drawn by other naturalists including the Italian Marcello Malpighi and Claude Perrault of the Académie royale des sciences. 
This combination of artistic skill and epistemic motivation was on display in Waller's most famous series of drawings. Within the period from 1689 to 1713 , Waller made a series of images of English wildflowers and grasses. He uses the English technique of limning to depict these native plants. These images have gained notice by scholars both for their beauty and also for their scientific merit (Griffing 2011). These twenty-two limned studies depict the plants in vibrant color, often with two specimens on the plate. Sometimes the plants are shown in their entirety with their roots, and other times Waller depicts them cut off at the stem, as in his depiction of oat grass (fig. 14). Floating next to the specimens, Waller also depicts details — drawn only in pencil—of the plants examined with a microscope, which were sometimes added at a later time (figs. 1, 14, 17). This project seems to have emerged from Waller's suggestion to make a visual companion to John Ray's Historia plantarum (1686) with images to serve as a pictorial reference for those "wholly ignorant" to identify plant species (Derham 1718, 211-212). He explains to Ray where he thinks the tables of images (i.e. plates) should be inserted in his book, as well as what botanical information the images should include. In proposing this visual strategy, Waller makes a claim for the immediacy of images to communicate taxonomical knowledge: "my design in these tables being only to give an idea of the difference of plants by pictures, (the representations of beings) rather than by words (the representations of pictures)"(Lankester 1848, 195-96). John Ray dismissed the scheme as too difficult, but Waller seems to have taken up an extended study of plants around this time regardless. Waller labeled each plant with both its Latin and common name, taking these from John Ray’s Synopsis Methodica Stirpium Britannicarum (1690), which was a pre-Linnean attempt to collate the names for the same plant across different authorities (Kusukawa 
2011, 14-15). Waller seems to have worked on this series over a period of several years and showed the images to his friends. On 4 April 1689, Robert Hooke records in his diary of seeing Waller's "curious painted plants" and again a week later "saw Wall[e]rs limn[e]d plants." At the end of the month Hooke indulged his friend again: "At Wallers more limbd plants." Over the next several years, Hooke's diary contains many notes with the same content: "At Wallers Saw his limned plants" (Gunther 1935, 111, 113, 117, 210).

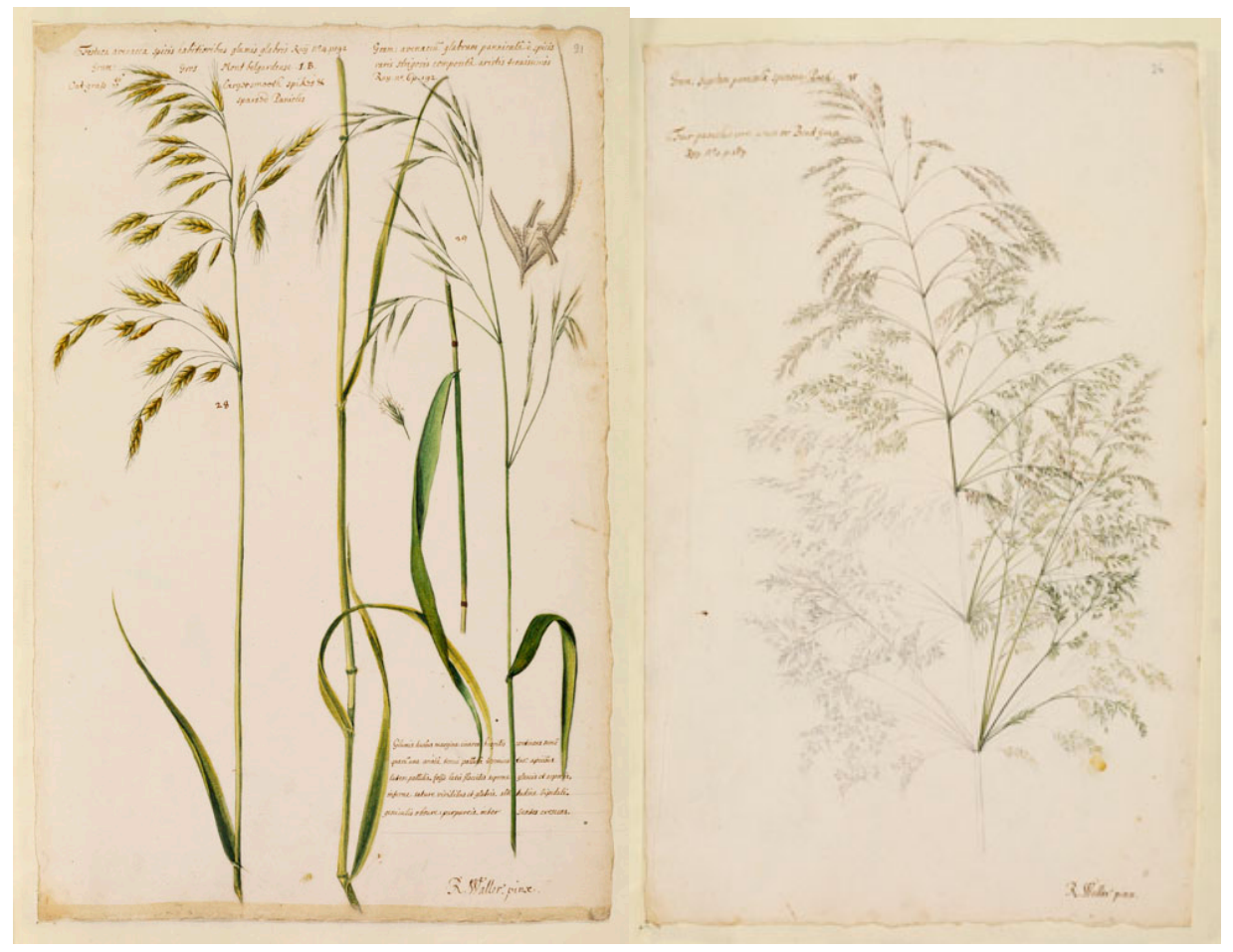

Figure 14 (Left): Richard Waller, Oat Grass with Smooth Spikes \& Sparsed Panicles, 1689. Watercolor on paper. 380 x 240mm. London, Royal Society Archives, MS/131/018. (Photo The Royal Society)

Figure 15 (Right): Richard Waller, Fair Panicled Corn Grass, or Bent Grass, 1689. Watercolor on paper. 380 x 240mm. MS/131/023, London, Royal Society Archives. (Photo Royal Society) 
In this series of grass studies, Waller achieves a balance between the aesthetic and the scientific. Waller's artistic abilities are on display in his careful composition of the flowers, portrayal of depth, and delicate application of color. The flowers are beautifully arranged and the compositions are balanced and visually appealing. Waller's unfinished Fair Panicled Corn Grass, or Bent Grass unveils some of the steps in the limning process (fig. 15). First, Waller laid down a delicate, branching underdrawing of the grass in pencil. Then Waller built up layers of pigment on top, starting with the lighter green and working to darker. His chosen technique, limning, was particularly appropriate for the purpose, as it allowed him to use a nuanced color palette in both diffuse and saturated applications. As William Salmon states in his drawing and engraving manual, "Limning is the Art whereby in water Colours, we strive to resemble Nature in every thing to the life" (Salmon 1672, 123). At the same time, the additional detail drawings of plant parts, analyzed with a microscope, demonstrate Waller's scientific interest in the morphology and function unique to each species. This balance of the aesthetic composition and scientific content is reminiscent of the Mémoires pour servir à l'histoire des plantes published by the French Académie royale des sciences in 1676 . To cut costs, the book's large engravings by Abraham Bosse, Nicholas Robert, and Louis de Châtillon, were based on source drawings from the vélins du roi royal collection (Stroup 1971, 71). However, the scientists of the French Academy objected when the artists they employed valued aesthetic choices (composition, lack of roots, etc.) over the botanically significant, if less beautiful, details. Without money for new plates, the artists tried to improve the existing ones by adding details, such as root structures and seeds, in the blank spaces (fig. 16) (Stroup 1971, 80-2). 
Though created by very different means in different circumstances, Waller's grass series creates a similar effect, balancing the beautiful with the informative.
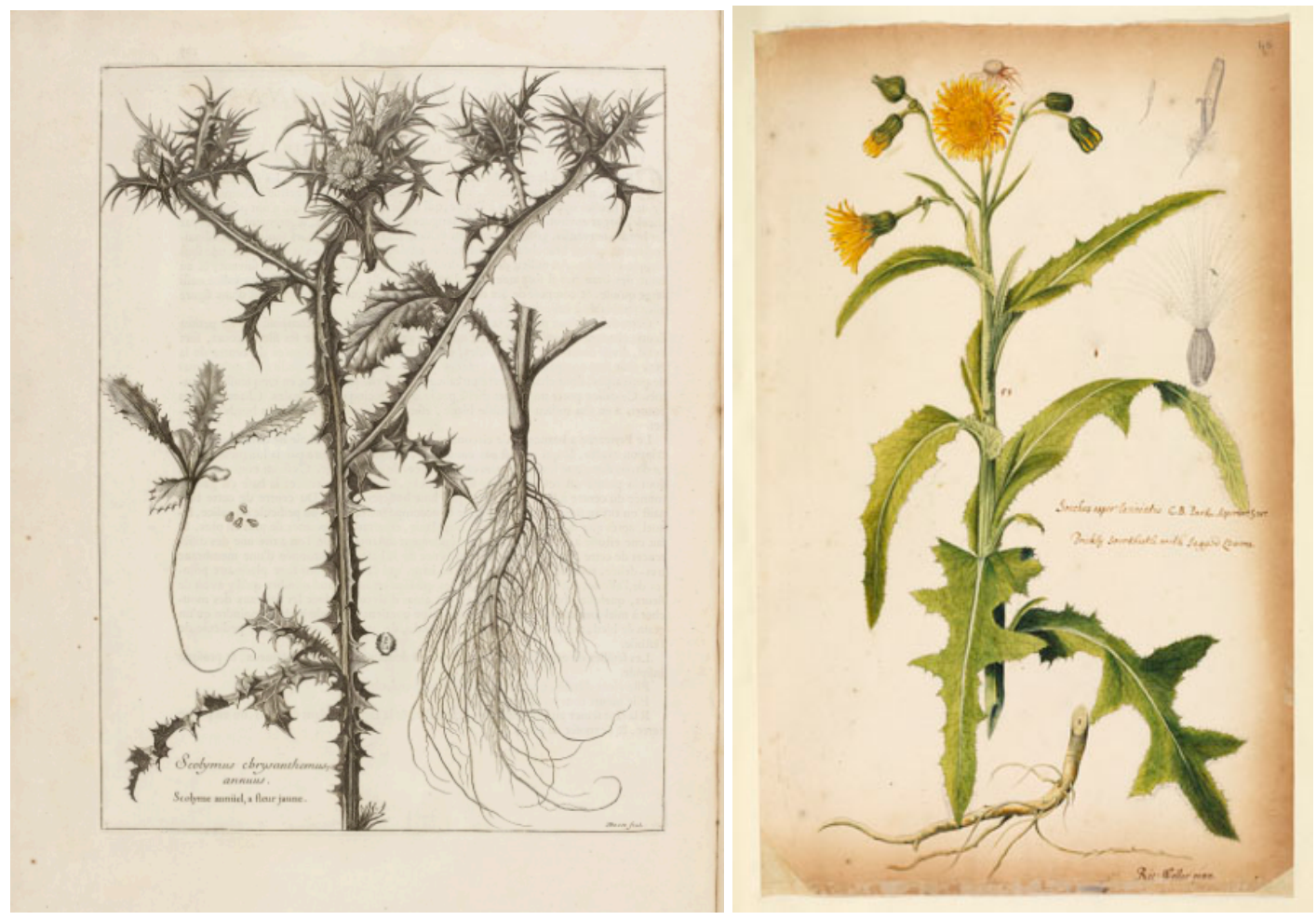

Figure 16 (Left): Abraham Bosse, Scolymus chrysanthemus annuus from Mémoires pour servir à l'histoire des plantes, 1676. Ink on paper, engraved. 58cm. Cambridge, Cambridge University Library, Rel.aa.67.4, p.110. (Photo The Cambridge University Library)

Figure 17 (Right): Richard Waller, Prickly sow-thistle with jagged leaves, 1689. Watercolor on paper. $380 \mathrm{x}$ 240mm. London, Royal Society Archives, MS/131/041. (Photo The Royal Society)

Waller's Frontispieces-Individual Skill \& Programmatic Statements

The two frontispieces Waller created on behalf of the Royal Society show a different side to his artistic thinking and activity within the Society. Waller brought in 
specimens, performed experiments, and created images, but as Felicity Henderson has shown, was also one of the Society's most active and prolific translators in its early years (Henderson 2013; 2017). Waller frequently translated letters and papers between Latin and European vernacular languages, and in the 1680s he was involved with two large monograph translation projects. In addition to the language translation, Waller designed the frontispieces for these two undertakings - translating the original images into programmatic statements on behalf of the Royal Society.

These images are an interesting source to analyze with regard both to Waller's graphic skill (this time in the medium of print) and to his engagement with frontispiece and allegorical traditions. In crafting new frontispieces for two continental texts, Waller created new statements on behalf of the Royal Society. As we will see, these frontispieces reflect both his artistic judgement and his knowledge of the layered meanings communicated in them.

Printmaking expanded greatly during the Restoration. In the second half of the seventeenth century, the creation, circulation, and demand for prints expanded in unprecedented ways. As Anthony Griffiths has argued, if the first half of the seventeenth century was a continuation of Elizabethan and Renaissance traditions in England, then the second half ushered in a more modern era of new ideas and innovations in printed images (Griffiths 1998, 23). The demand for prints increased greatly from 1660 onwards, new techniques such as the mezzotint fostered new interest, and improvements to printing technology made printing faster than ever before. The young Royal Society was very much a part of this trend, eager to include printed images in their own scientific works, and interested in the technology and mechanisms behind the process. As mentioned above, 
texts on various printing methods and techniques frequently circulated within the Royal Society, and Prince Rupert's mezzotint developments were introduced to England through their publication in Evelyn's Sculptura. Several members of the Royal Society, including Evelyn, Pepys, and Hooke, collected prints themselves (Kusukawa 2019). Griffiths points out that Evelyn, in his introduction to Fréart's An Idea of the Perfection of Painting (1668), speculates whether he should include the printed images in his edition, "considering that as this piece is of most use to the Virtuosi," but he decides against it as the Virtuosi, his readership, "are curious" and thus must "already be furnish'd with them" (Griffiths 1998, 27). The extent or content of Waller's print collection is unknown but given his wealth and standing it is fair to assume he either had a collection or had access to the prints of his friends, such as Hooke.

The creation of a frontispiece for a text was not unprecedented in the Royal Society, nor was Waller the first Fellow to design one. The 1667 frontispiece to Thomas Sprat's History of the Royal Society is one such example (fig. 18). Designed by Evelyn, and etched by Wenceslaus Hollar, the frontispiece depicts a bust of Charles II being crowned with a wreath by the goddess Fame. The bust of the patron is flanked on either side by two founding and formative figures: on the right by the Royal Society's first president, William, Viscount Brouncker; and on the left by Francis Bacon, depicted in his robes as Lord Chancellor and representing the intellectual aspirations of the young Society. Michael Hunter has recently published a thorough examination of this image in his book The Image of Restoration Science, and, with Jim Bennett, has identified both the various instruments and apparatus in the image and also the larger influences (Hunter 2017). He contends that that frontispiece was actually intended for another work-a 
defence of the Royal Society by John Beale, which he undertook when Sprat's volume seemed overly delayed. Hunter also shows how Evelyn's design owes a conceptual debt to a set of etchings by Nicholas Chaperon of biblical scenes that Raphael had depicted in the loggia at the Vatican. In this way, Evelyn's frontispiece - swapping Raphael for Charles II-substitutes the ambitions of Renaissance art for those of the New Science.

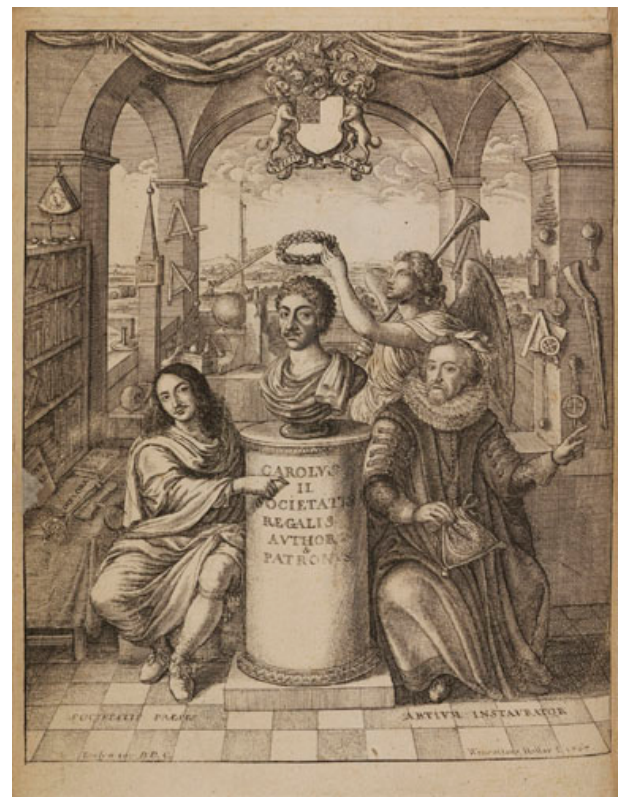

Figure 18: Wenceslaus Hollar after John Evelyn, Frontispiece to Thomas Sprat's The History of the Royal Society, 1667. Ink on paper, engraving. 238 x 175mm. London, Royal Society Collections (Photo The Royal Society)

This image is a good example of how frontispieces were often composite and layered images. Evelyn's design has both allegorical and literal elements, and simultaneously evokes the royal status of the Society in their coat of arms and with the bust of Charles II; the Baconian program that shaped the young group in the inclusion of Francis Bacon; and the daily activities of creating knowledge undertaken by the Society in the representations of their books and instruments. As Evelyn's image demonstrates, 
frontispieces were used to communicate multiple messages beyond signalling the book's content. These engraved images and the texts they accompany existed in what Volker Remmert has called a "complex web of intentions and receptions" (Remmert 2011, 5). Frontispieces were often used to appeal for or re-entrench patronage structures; they could be used to participate in philosophical debate (and Remmert has shown this in for the mathematical sciences: Remmert 2011; Corbett and Lightbown 1979). They could also be used to reinforce the authority or legitimacy of certain individuals, fields, programs of study, or institutions. Remmert and other scholars have shown very well that the multiple functions of frontispieces not only communicated the book's theme or acknowledged the patron, but could also convey more complex messages about power, prestige, and authorship. It is in this context that we must view Waller's two frontispieces.

In 1668, the Royal Society received a copy of the Saggi di naturali esperienzethe one and only publication from the short lived Tuscan society the Accademia del Cimento (1657-67). Presented to the Royal Society by Lorenzo Magalotti and Paulo Falconieri on behalf of the Cimento's patron, Prince Leopold de' Medici, "as a mark of his highness's esteem of the Society," the book contained the experiments on the nature of airs performed by the Italian group (Birch 1756, 2:256; Bosciero 2009). At their meeting, the Fellows thanked the two men for presenting the book, and they ordered that a letter of thanks be drawn up in Latin by Henry Oldenburg to be sent directly to the Prince. Finally, the Fellows ordered that Christopher Merret and William Balle "should be desired to peruse this book, and to give the Society an account of the contents of it, and the manner of treating several subjects in it" (Birch 1756, 4:256). Whether Merret and Balle reviewed the book but failed to report back, or if perhaps their Italian was not at a sufficient level to 
assess the work is unknown, but in any case it seems the task was quickly passed to Walter Pope and Robert Hooke. When the second pair made their report to the Society, they explained that many of the experiments described in the Saggi had already been performed at the Royal Society and "even improved beyond the contents of that book" (Birch 1756, 2:257; Bosciero 2009, 68). From all appearances the Saggi was then set aside. Yet, fifteen years later, long after the Cimento had disbanded, there was renewed interest in the book and calls for it to be translated. Scholars have given various reasons for this renewed interest, among them promoting Italian/English scientific connections and the growing popular interest in natural philosophy, but Luciano Bosciero contends it was the Fellows' renewed interest in the subject matter of pneumatics and the properties of air-the Saggi's chief concerns - that prompted the translation initiative (Bosciero 2009, 170). Whatever the exact motivations, in 1683 Waller made an English translation of the Italian volume, as well as designing and engraving a new frontispiece for the book and re-engraving the original plates.

The frontispiece to the original Saggi text depicts a large portrait of one of the Cimento's Medician patrons, Ferdinand II of Tuscany (fig. 19). The original frontispiece depicts the Grand Duke in three quarters view, elaborately dressed in armour and a large hat with generous plume. The image predates the publication as François Spierre engraved it in 1659 after a portrait of Ferdinand by Justus Sustermans. ${ }^{26}$ Below the frontispiece are four lines of text in Italian, which translate to:

\footnotetext{
${ }^{26}$ The original painting by Susterman now resides in the Uffizi in Italy. There is also a copy at Belton House, Linconshire that was likely a gift from Ferdinand's son Cosimo III to an ancestor of the Brownlow family on his visit to England in 1669.
} 
If to the great royal genius, heaven revealed

The unsolved mysteries of the sublime sphere

Today the vexed, imitative earth

Removes its veil to unknown marvels. ${ }^{27}$

The opposing title page contains a title engraving of an escutcheon-a decorated shield bearing Cimento's coat of arms (fig. 20). The Cimento's motto- 'provando e riprovando' (to try and try again) — appears on a rippling banner at the top. In addition to the frontispiece and title page, within the text of the book there are several engraved pages of apparatus, as well as several decorative letters and head and tail-pieces, some of which incorporate items of experimental equipment discussed in the text.

27 “Se al gran genio real, scoperse il cielo/Gli arcani intatti dell' eccelsa 'sfera/ Oggi la terra emulatrice altera/Toglie ad ignote maraviglie il velo." My thanks to Raymond Carleson and Irene Cooper for help with this translation. 


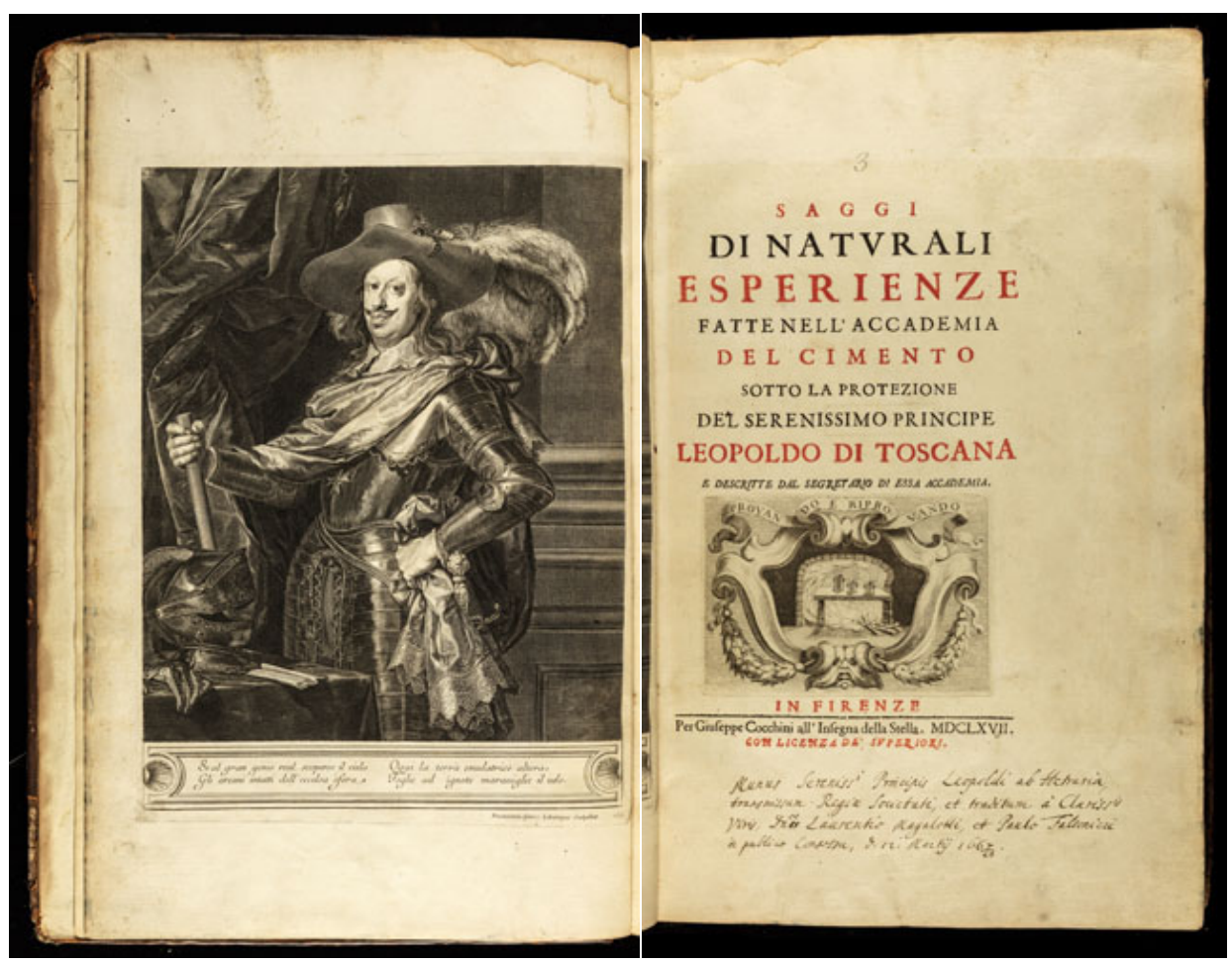

Figures 19 \& 20: Frontispiece and Title Page to the Saggi di naturali esperienze, 1668. Ink on paper, engraving. $36 \mathrm{~cm}$. London, Royal Society Library (Photo The Royal Society).

Whereas Waller engraved new plates for his edition based on the original images of experimental equipment (staying faithful to their content, if sometimes re-allocating the spacing), the frontispiece to his translated volume was an entirely new and original design (fig. 21). Instead of a patronage portrait, Waller created an allegorical frontispiece that made a statement about natural knowledge more broadly. The scene depicts four allegorical figures, which Waller identifies through labels on the hemlines of their cloaks. To the left stand the figures of Aristotle and Divine Nature; and on the right are personifications of the Accademia del Cimento and the Royal Society. The Accademia del Cimento is adorned with an escutcheon bearing the Cimento's coat of arms (taken from the original title page) and their motto trails around it on a ribbon. The figures bear 
stylistic resemblance to Waller's youthful Aeneid figures, and reveal a mature, more refined technique; the figures are more proportioned and the faces are balanced.

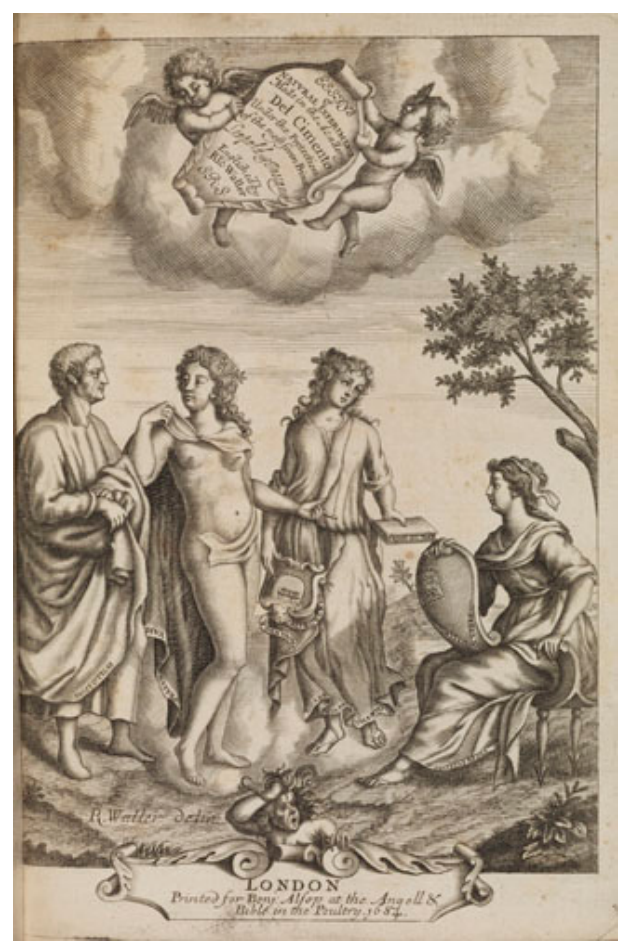

Figure 21: Richard Waller, Frontispiece to Essays of Natural Experiments made in the Academie del Cimento, 1684. Ink on paper, engraving. 220 x 148mm. London, Royal Society Library (Photo The Royal Society of London)

The image speaks to the transfer of knowledge - the personified Cimento hands the seated Royal Society the Saggi, while Aristotle and Nature look on approvingly. This scene of knowledge personified dominates the frontispiece, while the attribution of the book's title and translator are moved to a tablet carried above by two putti. At the bottom of the image a wild-haired fury peeps over the printer's information, seemingly enraged by the collaboration of natural knowledge taking place above.

In this instance, Waller deployed his visual judgement to craft a frontispiece more appropriate to the volume's new audience. The original —a full sized tribute to the Tuscan 
Patron - would have been misplaced in the English translation, both because the image could no longer do any effective patronage work after the Cimento had essentially dissolved, and also because the identity of the sitter would likely be meaningless to the new English audience. Instead, Waller created an allegory of what his book is doing; in giving the Saggi an English dress, its knowledge is effectively being passed from Italian to English hands. In doing so Waller evoked the authority of the Royal Society—-though they had no hand in creating the text of the Saggi, Waller allegorically implies they have become the guardians of its knowledge.

Waller made a very different set of decisions for the second frontispiece he created. Though also the publication of a sister European institution, Mémoires pour servir à l'histoire des animaux (1671) was a very different text from the Saggi. Histoire des animaux was the first major publication of the French Académie royale des sciences (founded in 1666) and was a lavish affair. Based on a series of animal dissections from King Louis XIV's menagerie, the resulting volume issued by the Academy was large, expensive to produce, and, subsequently, rare and exceptional. At a time when an average print run was one thousand copies, the royal printer only produced around two hundred copies of Histoire des animaux in its initial printing in 1671 (Guerrini 2010, 289-90). ${ }^{28} \mathrm{~A}$ second volume followed in 1676 following the same format. The folio volume was bound in red morocco with a gold embossed fleur-de-lis on the cover. It was printed on highquality paper and the full-page engravings of each animal cost over 4,000 livres to produce. The Royal Society kept well aware of the work and progress of the French

${ }^{28}$ Guerrini notes that the London Stationers' Company considered a print run of fewer than eight hundred copies uneconomical at this time, Guerrini 2010, 289-90. 
Academy, and published an announcement of the book in the Philosophical Transactions. However, it was not until the 1680s that the Royal Society was able to procure their own copy.

When a copy finally came on the market, Hooke quickly alerted Waller. He wrote a letter to thank Hooke "for the trouble you have taken to procure the Memoires and have now wrote to my $\mathrm{Br}$ [other] Pitfeield to buy them for me without delay, least as you wrote they should be gone." ${ }^{29}$ From the letter it seems it was initially Waller who was meant to translate the work (though he questioned if he was "capable of making them speake English properly"), but in the end the task fell to Waller's brother in law Alexander Pitfield (though Waller would translate Mesure de la Terre, another folio volume from the French Academy, this time on astronomy, that was published by the Royal Society with the translated Histoire des animaux). In the introduction to his translation, Pitfield felt the need to comment on the lavishness of the book and also to complain about its difficulty to obtain:

so Magnificently, as well as Curiously set forth in two Volumes, that (as they seemed not to be designed for common Sale, so) they became Presents only from the King, or Academy, to Persons of the greatest Quality, and were hereby rendered unattainable by the ordinary Methods for other Books. And altho' by some few, who (through this means) had the opportunity of perusing them, they were found full fraught with very Pertinent, as well as Curious Observations; yet so great was the difficulty in procuring the favour of Such a perusal (not only here in England, but

\footnotetext{
${ }^{29}$ British Library, Sloane MS 4067, 198r.
} 
even at Paris it self) that the Ingenious Labours of that Illustrious Society were hereby made less Useful and Ineffectual to their great Design; most of the Learned being totally deprived of the singular Advantages that might be obtained there from (Pitfield in Perrault 1688).

A key feature making these volumes "so magnificently set forth" were the engravings executed primarily by Sébastien LeClerc. A member of the French Académie royale de peinture et de sculpture, LeClerc was prominent artist in his own time, frequently undertaking work on behalf of royal institutions or King Louis XIV himself (Préaud 1980). Anita Guerrini has argued for the importance of LeClerc's animal dissection images for the prestige of the volume, but in addition, LeClerc also engraved a frontispiece that would be used for several of the Academy's early publications (fig. 22). LeClerc's engraving of the King's imagined visit to the Academy depicts the people, spaces, and objects that were critical to the productivity and success of the young state institution. In the center of the image, the King's chief minister, Jean-Baptiste Colbert, presents the Academy to the monarch, and its members crowd around the sovereign. Human and animal skeletons — artefacts of the Academy's anatomical investigations — adorn the far wall. A globe, an armillary sphere, and a telescope symbolize the group's astronomical pursuits. Vials, flasks, and plant specimens represent its chemical and botanical work. In the background, through the library's windows, we can see the Jardin des Plantes and the massive new observatory, still under construction. Yet, as Alice Stroup and many others have noted, this image is a famous fiction—neither the gardens nor the observatory could be seen from the Bibliothèque du Roi, and the King would not visit the Academy for 
another fifteen years (Stroup 1971, 5-8; Hahn 1971). LeClerc's frontispiece served as a programmatic statement about the work of the Academy, but also emphasized the royal patron to whom the Academy owed their sponsorship and salaries (and were subsequently subservient). The scene of the Sun King's visit to France's Académie royale des sciences also served a public function, impressing upon all who envisioned it the connection between natural philosophical knowledge and political power-between science and statecraft.

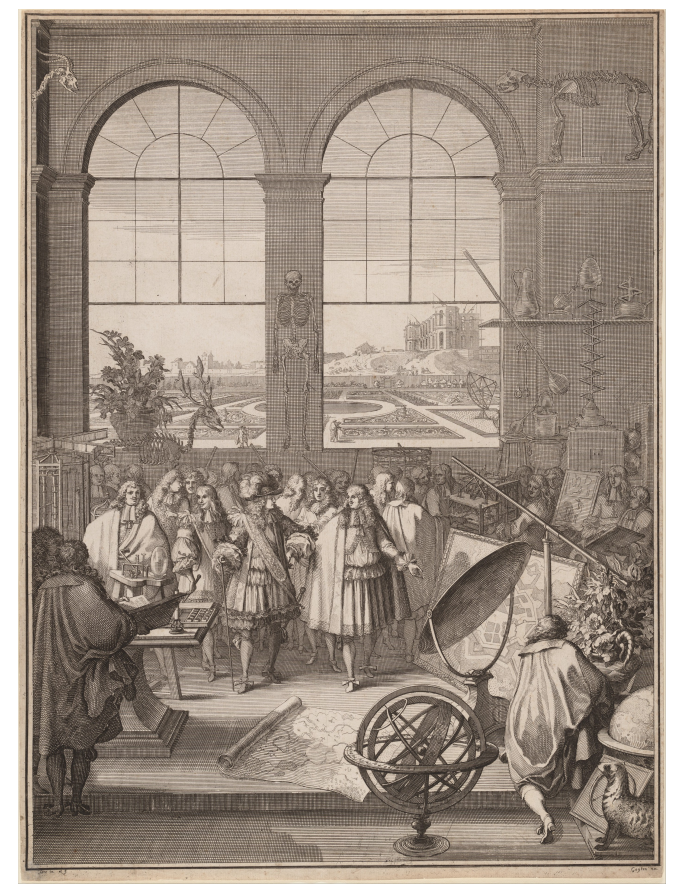

Figure 22: Sébastien LeClerc, Frontispiece to Mémoires pour servir à l'histoire naturelle des animaux, 1671. Ink on paper, engraved. 260 x 400mm. Cambridge, Cambridge University Library, Rel.aa.67.1. (Photo The Cambridge University Library)

When Pitfield gave the Histoire des animaux an "English dress" it was published in quarto - a much smaller format than the French original. To preserve the information communicated in the images, Waller re-engraved the plates of animal dissections to 
accommodate the smaller format, which F.J. Cole called "little better than caricatures of the masterly originals of Sébastien Leclerc" (Cole 1949, 400). Whatever the assessment of the quality, that Waller undertook to re-engrave all of the plates indicates his facility working in the specialized medium of intaglio printing. The volume also needed a new frontispiece. As with the Saggi, it perhaps seems obvious that Waller would change the subject of the frontispiece away from the original patronage messages (after all the French King was not paying for this publication, nor would Waller or the Royal Society likely want to promote the dominance of French state science), but the decisions Waller made for this frontispiece are decidedly different from those he made for the Saggi. In Waller's engraving we see Waller borrow from LeClerc's iconography, with the title information on a platform of architecture and cloth, adorned with animal skeletons, with two putti attempting to avert their eyes (fig. 23). This scene has an almost haunting momento mori quality, beyond what it is literally doing — evoking the subject of the text, animal dissection. 


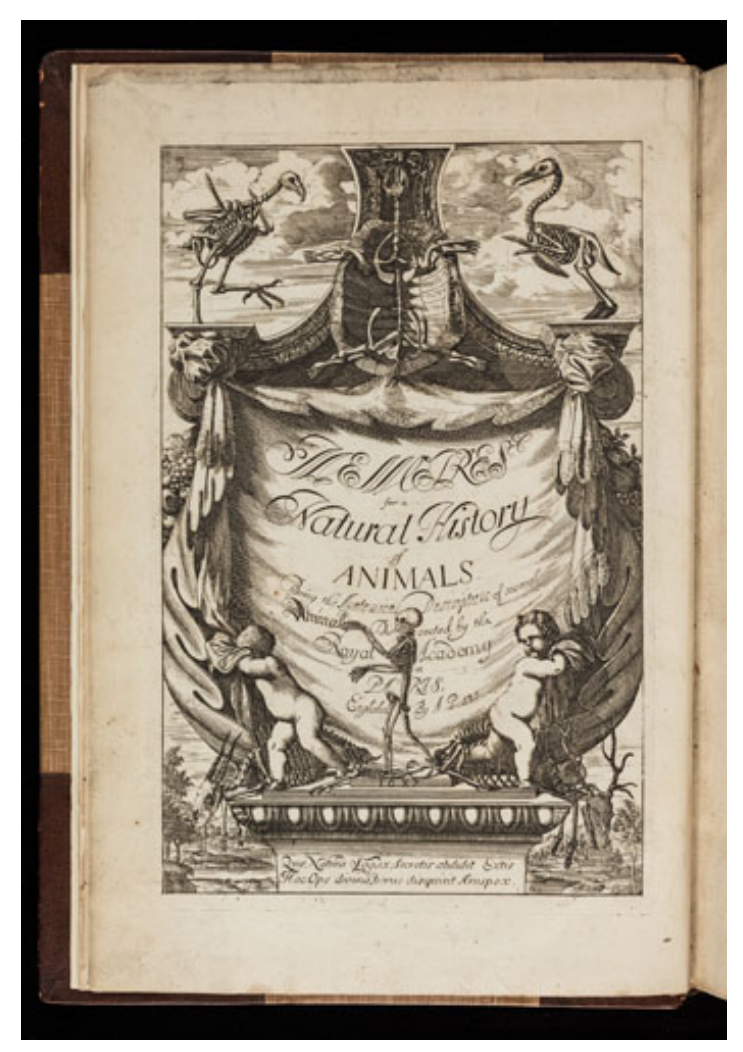

Figure 23: Richard Waller, Frontispiece to Memoirs for a Natural History of Animals, 1688. Ink on paper, engraving. 195 x 143mm. London, The Royal Society (Photo The Royal Society)

However, unlike his frontispiece for the Saggi translation, Waller did not create an entirely new iconography for this image. The visual components of his engraving are taken from one of LeClerc's culs-de-lampe (or tailpieces) used throughout the original French text (fig. 24). Waller copies LeClerc's skeletal cul-de-lampe in a simplified version in his own cul-de-lampe (fig. 25). For this volume, Waller made different visual choices assembling motifs from the famous source material, basing his design on the compositional elements from LeClerc's lavish engravings. The Mémoires frontispiece evokes the specific content of the volume (anatomy) rather than allegorical knowledge more broadly. In this instance, perhaps Waller wanted to keep a closer visual link to 
images in the original, as the French book (and its images) would have been more widely known than those in the Saggi, due to the prominent artist, LeClerc, who created them.

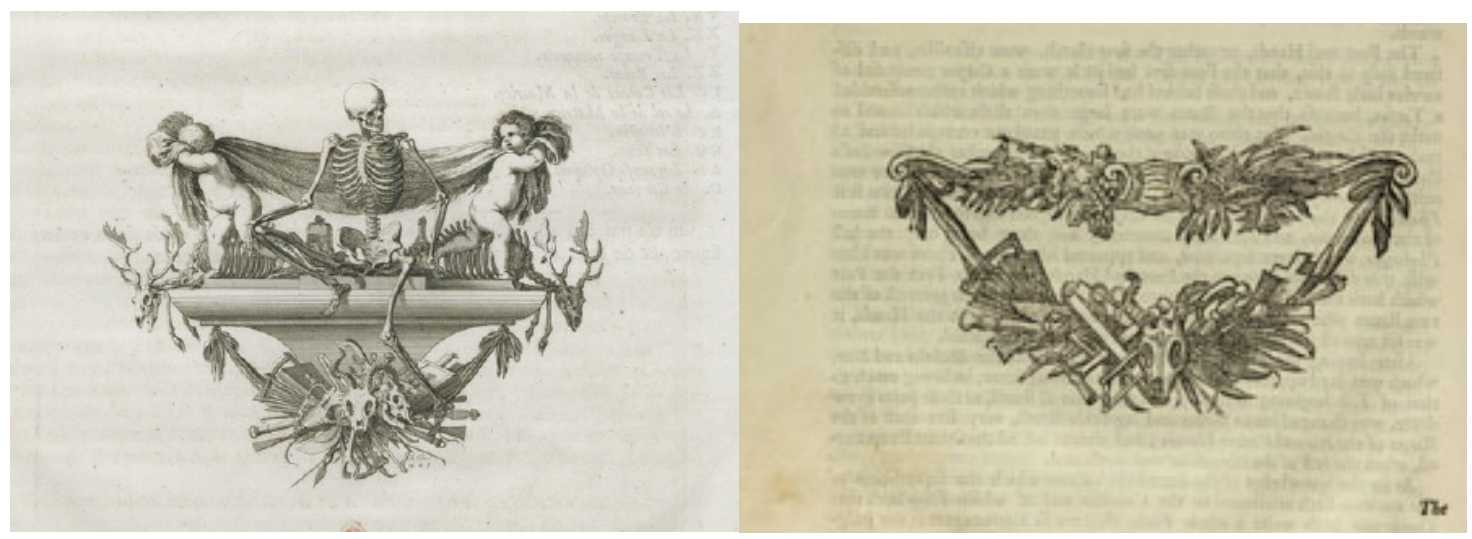

Figure 24 (Left): Sébastien LeClerc, Cul-de-lampe from Mémoires pour servir à l'histoire naturelle des animaux (detail), 1671. Ink on paper, engraved. Cambridge, Cambridge University Library, Rel.aa.67.1. (Photo The Cambridge University Library)

Figure 25 (Right): Richard Waller, cul-de-lampe from Memoirs for a Natural History of Animals (detail), 1688. Ink on paper, engraving. London, The Royal Society (Photo The Royal Society)

In these two frontispieces, Waller displays different aspects of his visual acumen and graphic skill. In the Saggi frontispiece, Waller mobilized his skills in figuration and allegory. He composed a scene more appropriate to the translated Saggi's audience, but also one promoting the Royal Society. In the Histoire des animaux frontispiece, Waller capitalized on the quality and fame of LeClerc's engravings and utilized his skills to copy precisely and recompose visual themes from the original masterworks. For both images Waller needed to translate European iconography and patronage statements into visual messages appropriate, and meaningful to his English audiences. 
Waller's two frontispieces are a very different type of image than the drawings and paintings previously discussed. Here Waller's knowledge of printing craft and tradition were on display. Neither image was intended to communicate scientific knowledge itself; rather both communicated more abstract messages about the relationship of knowledge, books, and the societies that create them. In crafting these frontispieces, Waller created images that were intended to be seen by — and thus communicate their message - to a viewership beyond the rosters of Royal Society members.

\section{Conclusion}

It would be misleading to claim Waller was the only natural philosopher, or even Royal Society member, with this diverse array of visual and graphic skills. His friend Robert Hooke apprenticed with the painter Peter Lely and frequently composed images; John Evelyn designed the Sprat frontispiece. In Paris, the physician and architect Claude Perrault, much like Waller, was often called on by the French Academy to record visually a dissection or experiment because, in part, of his greater degree of skill than his colleagues. Many of Waller's peers and contemporaries participated in the visual component of early modern natural philosophy. In this way, Waller is a representative example of how closely image-making and science were linked in this period. However, in other ways Waller stands out for the quantity, quality, and range of the images he produced as part of the Royal Society. He applied his diverse image-making skills to the pursuit of collective science, and this contribution should not be overlooked or dismissed.

Richard Waller was both an image-maker and a natural philosopher, and both pursuits are critical to any assessment of his influence on the formative years of Royal 
Society. By looking at the variety and scope of Waller's work in the context of his own scientific curiosity and of contemporary image-making traditions, a more comprehensive view emerges of this under-studied figure and the relationship between his graphic skill and the production of knowledge. 


\section{References}

[Accademia del Cimento]. 1667. Saggi di naturali esperienze fatte nell'Accademia del cimento sotto la protezione del serenissimo principe Leopoldo di Toscana e descritte dal segretario di essa accademia. Edited by Lorenzo Magalotti. Florence: Giuseppe Cocchini.

Bermingham, Ann. 2000. Learning to Draw: Studies in the Cultural History of a Polite and Useful Art. New Haven and London: Yale University Press.

Birch, Thomas. 1756-57. The History of the Royal Society of London for Improving of Natural Knowledge. 4 vols. London: printed for A. Millar.

Boschiero, Luciano. 2009. "Translation, Experimentation and the Spring of the Air: Richard Waller's Essayes of Natural Experiments." Notes and Records of the Royal Society 64:67-83.

Cole, F.J. 1949. A History of Comparative Anatomy: From Aristotle to the Eighteenth Century. London: Macmillan \& Co Ltd.

Coombs, Katherine and Alan Derbyshire. 2015. “Nicholas Hilliard's Workshop Practice Reconsidered," in Painting in Britain, 1500-1630, Tanya Cooper, Aviva Bunstock, Maurice Howard, and Edward Town (eds.), Oxford: Oxford University Press. 
Corbett, Margery, and R. W. Lightbown. 1979. The Comely Frontispiece: The Emblematic Title-Page in England, 1550-1660. Boston: Routledge and Kegan Paul.

De Beer, Esmond Samuel. 2000. The Diary of John Evelyn: Now Printed in Full From the Manuscripts Belonging to Mr. John Evelyn. 6 vols. Oxford: Oxford University Press.

Dodart, Denis, et al. 1676. Mémoires pour servir à l'histoire naturelle des plantes. Paris: Imprimerie royale.

Egmond, Florike. 2017. Eye for Detail: Images of Plants and Animals in Art and Science 1500-1630. London: Reaktion Books.

Evelyn, John. 1662. Sculptura, or, The history, and art of chalcography and engraving in copper with an ample enumeration of the most renowned masters and their works: to which is annexed a new manner of engraving, or mezzo tinto, communicated by His Highness Prince Rupert to the authour of this treatise. London: Printed by J.C. for G. Beedle and T. Collins.

Ezell, Margaret J. M. 1984. "Richard Waller, S. R. S.: 'In pursuit of nature'." Notes and Records of the Royal Society 38:215-33.

Ezell, Margaret J. M. 1987. The Patriarch's Wife: Literary Evidence and the History of the Family. Chapel Hill and London: University of North Carolina Press. 
Faraday, Christina. 2019. “Facial Recognition,” Apollo Magazine, 189:134-139.

Goldring, Elizabeth. 2019. Nicholas Hilliard: Life of an Artist. New Haven and London: Yale University Press.

Griffing, Lawrence R. 2011. “Who Invented the Dichotomous Key? Richard Waller's Watercolors of the Herbs of Britain.” American Journal of Botany 98:1911-23.

Griffiths, Antony, and Robert A. Gerard. 1998. The Print in Stuart Britain, 1603-1689. London: British Museum Press for the Trustees of the British Museum.

Guerrini, Anita. 2010. "The King's Animals and the King's Books: The Illustrations of the Paris Academy's Histoire des animaux." Annals of Science 67:383-404.

Gunther, R.T. 1935. Early Science in Oxford, vol. X: The Life and Work of Robert Hooke (part IV). Oxford: Oxford University Press.

Hahn, Roger. 1971. The Anatomy of a Scientific Institution: The Paris Academy of Sciences, 1666-1803. Berkeley: University of California Press.

Hallet, Mark, Nigel Llewellyn, and Martin Myrone. Court, Country, City: British Art and Architecture, 1660-1735. New Haven and London: Yale Center for British Art and the 
Paul Mellon Centre for British Art.

Hanson, Craig Ashley. 2009. The English Virtuoso: Art, Medicine, and Antiquarianism in the Age of Empiricism. Chicago: University of Chicago Press.

Henderson, Felicity. 2013. "Faithful Interpreters? Translation Theory and Practice at the Early Royal Society." Notes and Records of the Royal Society 67:101-22.

Henderson, Felicity. 2017. "Translation in the Circle of Robert Hooke.” Pp 17-40 in Translating Early Modern Science. Edited by Sietske Fransen, Niall Hodson, and Harl A. E. Enenkel. Leiden: Brill.

Henderson, Felicity. 2019. "Robert Hooke and the Visual World of the Early Royal Society." Perspectives on Science.

Henderson, Felicity (ed.). [Forthcoming] The Diary of Robert Hooke.

Hunter, Matthew C. 2010. "Hooke's Figurations: A Figural Drawing Attributed to Robert Hooke." Notes and Records of the Royal Society 64:251-60.

Hunter, Matthew C. 2013. Wicked Intelligence: Visual Art and the Science of Experiment in Restoration London. Chicago and London: The University of Chicago Press. 
Hunter, Michael (ed.). 1998. Archives of the Scientific Revolution: The Formation and Exchange of Ideas in Seventeenth-Century Europe. Woodbridge: The Boydell Press.

Hunter, Michael. 1989. Establishing the New Science: The Experience of the early Royal Society. Woodbridge: The Boydell Press.

Hunter, Michael (ed.). 2010. Printed Images in Early Modern Britain: Essays in Interpretation. Farnham: Ashgate.

Hunter, Michael, (with a chapter by Jim Bennett). 2017. The Image of Restoration

Science: The Frontispiece to Thomas Sprat's History of the Royal Society (1667). London: Routledge.

Hunter, Michael. 1982. The Royal Society and Its Fellows 1660-1700: The Morphology of an early Scientific Institution. Oxford: BSHS Monographs.

Kusukawa, Sachiko. 2011. "Picturing Knowledge in the Early Royal Society: The Examples of Richard Waller and Henry Hunt." Notes and Records of the Royal Society 65:273-94.

Kusukawa, Sachiko. 2013. "The Fossil Drawings by Robert Hooke and Richard Waller." Notes and Records of the Royal Society 67:123-38. 
Kusukawa, Sachiko. 2015. "Richard Waller's Colour Chart (1686)." Pp 3-21 in Colour

Histories: Science, Art, and Technology in the 17th and 18th Centuries. Edited by

Friedrich Steinle and Magdalena Bushart. Berlin: W. de Gruyter.

Kusukawa, Sachiko. 2019. "The Early Royal Society and Visual Culture." Perspectives on Science.

Lankester, Edwin (ed.). 184 8. The Correspondence of John Ray. London: Printed for the Ray Society.

Leonhard, Karin. 2015. "Painted Gems. The Color Worlds of Portrait Miniature Painting in Sixteenth- and Seventeenth-Century Britain," Early Science and Medicine, 20:428-57.

Middleton, W.E. Knowles. 1971. The Experimenters: A Study of the Accademia del Cimento. Baltimore: Johns Hopkins University Press.

Moxham, Noah. 2015. "Fit for Print: Developing an Institutional Model of Scientific Periodical Publishing in England, 1665-ca. 1714." Notes and Records of the Royal Society 69:241-60.

Moxham, Noah. 2016. “An Experimental 'Life' for an Experimental Life: Richard Waller's Biography of Robert Hooke (1705)." British Journal for the History of Science 49:27-51. 
Murdoch, John, and Jim Murrell, Patrick J. Noon, Roy Strong. 1981. The English Miniature. New Haven and London: Yale University Press.

Norgate, Edward. 1997. Miniatura or the Art of Limning. Jeffrey M. Muller and Jum Murrell (eds.). New Haven and London: Yale University Press and Paul Mellon Centre for British Art.

Peacham, Henry. 1634. The Compleat Gentleman: Fashioning him absolut in the most necessary and commendable qualities concerning mind or body, that may be required in a noble gentleman. London: Constable.

Perrault, Claude, et al. 1671-76. Mémoires pour servir à l'histoire naturelle des animaux. 2 vols. Paris: Imprimerie royale.

Perrault, Claude. 1688. Memoirs for a Natural History of Animals: containing the anatomical descriptions of several creatures dissected by the Royal Academy of Sciences at Paris. Translated by Alexander Pitfield. London: J. Streater [pt 2: by R. Roberts], sold by T. Basset [et al.].

Préaud, Maxime. 1980. Inventaire du fonds français. Graveurs du XVIIe siècle. Sébastien Le Clerc I \& II, (Tome 8\&9). Paris: Bibliothèque Nationale. 
Redi, Francesco, and Alex Macalister. 1671. Francisci Redi... Experimenta circa generationem insectorum ad nobilissimum virum Carolum Dati. Amstelodami: sumptibus Andre $\mu$ Frisii.

Remmert, Volker R. 2006. “'Docet parva picture, quod multae scripturae non dicunt': Frontispieces, their Functions, and their Audiences in Seventeenth-Century Mathematical Sciences." Pp 239-270 in Transmitting Knowledge: Words, Images, and Instruments in Early Modern Europe. Edited by Sachiko Kusukawa and Ian Maclean. Oxford: Oxford University Press.

Remmert, Volker R. 2011. Picturing the Scientific Revolution. Philadelphia: Saint Joseph's University Press.

Salmon, William. 1672. Polygraphice, or, The art of drawing, engraving, etching, limning, painting, washing, varnishing, colouring, and dying in three books: I, shews the drawing of men and other animal creatures, landskips, countries, and figures of various forms, II, the way of engraving etching and limning with all their requisits and ornaments, III, the way of painting, washing, varnishing, colouring and dying according to the method of the best authors now extant, exemplified in the painting of the antients, washing of maps, globes or pictures, dying of cloth, silks, bones, wood, glass, stones, and metals, together with the way of varnishing thereof according to any purpose or intent: the like never yet extant. London: Printed by E. T. and R. H. for Richard Jones. 
Sloan, Kim. 2000. “A Noble Art”: Amateur Artists and Drawing Masters c.1600-1800. London: Trustees of the British Museum.

Sprat, Thomas, and Abraham Cowley. 1667. The History of the Royal-Society of London for the Improving of Natural Knowledge. London: Printed by T. R. for J. Martyn.

Strong, Roy. 1983. The English Renaissance Miniature. London:Thames and Hudson.

Stroup, Alice. 1990. A Company of Scientists: Botany, Patronage, and Community at the Seventeenth-Century Parisian Royal Academy of Sciences. Berkeley: University of California Press.

Teague, Frances, and Margaret J. M. Ezell. 2016. Educating English Daughters: Late Seventeenth-Century Debates. Toronto: Iter Academic Press.

Thomas, Ben. 2010. "Noble or Commerical? The Early History of Mezzotint in Britain," Pp 279-296 in Printed Images in Early Modern Britain: Essays in Interpretation. Edited by Michael Hunter. Farnham: Ashgate.

Waller, Richard. 1684. Essayes of Natural Experiments: Made in the Academie del cimento, under the protection of the most serene Prince Leopold of Tuscany. London: printed for B. Alsop. 
Waller, Richard. 1685. "Observations on the Cicindela Volans, or Flying Glowworm, with the figure thereof made, and Designed by Richard Waller Esq. of the R.S." Philosophical Transactions 15(167):841-5.

Waller, Richard. 1686. "Tabula colorum physiologica tam mixtorum quam simplicium quadrilinguis una cum speciminibus adjectis." Philosophical Transactions 16(179):24-32.

Walpole, Horace. 1762. Anecdotes of Painting in England, with Some Accounts of the Principal Artists. London: Alexander Murray. 